\title{
EVALUASI MEKANISME PENYUSUNAN CASH FORECASTING PEMERINTAH PUSAT DENGAN FRAMEWORK GFOA
}

\author{
Anang Febri Sulistyono \\ Direktorat Jenderal Perbendaharaan \\ Alamat Korespondensi: anangfebri00@gmail.com
}

\begin{abstract}
This paper aims to investigate as to how central government of Indonesia develops its cash forecasting compared with the forecasting framework published by GFOA (Government Finance Officers Association) (2013). The study is focused on examining daily and monthly cash flow forecasting during the fiscal year of 2015 - 2016. The data required to perform the comparison are collected from interviews involving the operators, regulators and/or the person in charge of preparing the forecast. Data analysis is carried out using qualitative methodassisted by several software, such as: Microsoft Office Excel and $N$-VIVO. The study concludes that the preparation of cash forecasting by the central government of Indonesia doesn't fully correspond with the framework published by GFOA. There are some differences related to the scope of the forecast, time-frame of the forecast, exploratory analysis, and also how the financial managers are using the forecast.
\end{abstract}

KATA KUNCI:

Public finance, fiscal policy, fiscal forecast, financial forecast.

\begin{abstract}
ABSTRAK
Tulisan ini bertujuan untuk mengetahui bagaimana Pemerintah Pusat menyusun cash forecasting dibandingkan dengan framework yang di-publish oleh GFOA (Government Finance Officers Association) (2013). Objek penelitian adalah mekanisme penyusunan RPD Harian, RPD Bulanan, RPnD, Proyeksi Penerimaan dan Pengeluaran periode tahun anggaran 2015 dan 2016. Data penelitian bersumber daridata sekunder dan juga dataprimerberupa wawancara mendalam dengan operator dan regulator proyeksi kas pemerintah. Analisis data dilakukan dengan bantuan aplikasi N-VIVO dan Microsoft Office Excel. Hasil penelitian menunjukkan bahwa mekanisme penyusunan cash forecasting pemerintah pusat belum sepenuhnya sesuai dengan framework GFOA. Terdapat berbagai perbedaan dengan frameworkdiantaranya terkait dengan lingkup tujuan perencanaan kas, time-frame, exploratoryanalysis, maupun penggunaan cash forecastingoleh pengelola keuangan.
\end{abstract}

KLASIFIKASI JEL:

H30, H50, H68, G17 


\section{PENDAHULUAN}

\subsection{Latar Belakang}

'Cash is king' merupakan expression yang digunakan para analis maupun pengelola keuangan untuk mendeskripsikan pentingnya arus kas. Hal ini berarti arus kas merupakan salah satu hal pokok yang menentukan keberlangsungan hidup suatu entitas (Suwardi: 2012). Suwardi juga menyatakan bahwa arus kas yang lancar merupakan hal penting bagi unit bisnis maupun entitas publik/instansi pemerintah.

Bagi pemerintah, kas adalah salah satu variabel yang diperlukan dalam proses pengambilan kebijakan maupun pelaksanaan kegiatan. Semakin banyak kas yang tersedia, semakin fleksibel pula alternatif kebijakan strategis yang dapat dilakukan. Dengan kata lain, kemampuan pemerintah untuk mengelola dan menyediakan kas adalah hal yang krusial.

Salah satu pilar dalam pelaksanaan pengelolaan kas pemerintah adalah perencanaan kas yang akurat dan tepat waktu (Indra dan Adam: 2014). Perencanaan kas penting untuk membantu pemerintah menjamin ketersediaan kas pada suatu periode dan memastikan kecukupan saldo kas untuk memenuhi kewajiban pemerintah melakukan pembayaran dalam rangka pelaksanaan Anggaran Pendapatan dan Belanja Negara (APBN). Selain itu, perencanaan kas yang akurat akan meningkatkan kualitas penyerapan anggaran yang proporsional (Yudhiyanto dalam Seftianova dan Adam: 2013). Perencanaan kas yang akurat juga turut membantu kebijakan moneter yang dilakukan oleh Bank Sentral (Mu: 2006).

Menyadari akan pentingnya peran perencanaan kas, pemerintah menerbitkan Peraturan Pemerintah Nomor 39 Tahun 2007 tentang Pengelolaan Uang Negara/Daerah (PP 39 Tahun 2007). Peraturan Pemerintah tersebut memberikan tanggung jawab penyusunan perencanaan kas dan penetapan saldo minimal (cashbuffer) kas negara kepada Menteri Keuangan selaku Bendahara Umum Negara (BUN). Selain itu, diwajibkan pula bagi kementerian negara/lembaga (K/L) yang memiliki kaitandengan penerimaan dan pengeluaran APBN untuk menyampaikan proyeksi penerimaan dan pengeluaran secara berkala kepada BUN.

Saat ini, peraturan yang memayungi penyusunan perencanaan kas Pemerintah Pusat adalah PMK Nomor 197/PMK.05/2017 tentang Rencana Penarikan Dana (RPD), Rencana Penerimaan Dana (RPnD), dan Perencanaan Kas. PMK ini mengandung berbagai penyempurnaan mekanisme perencanaan kas dari berbagai peraturan pendahulu dengan memperhatikan masukan dari satuan kerja (satker) dan KPPN serta best practice penyusunan proyeksi kas di beberapa negara yang lebih maju. ${ }^{1}$

PMK-197 tahun 2017 mengamanatkan bahwa Menteri Keuangan selaku Bendahara Umum Negara (BUN) bertanggung jawab untuk menyusun perencanaan kas pemerintah. Tanggung jawab penyusunan perencanaan kas tersebut dilaksanakan oleh Direktur Jenderal Perbendaharaan (DJPb) c.q. Direktorat Pengelolaan Kas Negara (Direktorat PKN) selaku Kuasa BUN Pusat. PMK-197 tahun 2017 juga mengamanatkan bahwa menteri negara/pimpinan lembaga bertanggung jawab atas penyusunan RPD. RPD sebagaimana dimaksud dalam PMK-197 tahun 2017 terdiri dari RPD harian dan RPD bulanan.

Akurasi data penarikan dana dalam RPDsangatlah penting. Hasibuan (2016) mengungkapkan bahwa ketepatan waktu penyampaian dan akurasi RPD satker sangat berpengaruh terhadap akurasi perencanaan kas secara nasional. Bila deviasi RPD satker terlalu besar, perencanaan kas pemerintah menjadi tidak reliable.

Berdasarkan data pengiriman RPD secara nasional pada tahun 2015-2016, tingkat akurasi RPD belum menunjukkan nilai yang maksimal karena memiliki deviasi yang besar (seperti nampak pada Tabel 1). Deviasi paling tinggi mencapai $100 \%$ pada awal tahun 2015. Sedangkan

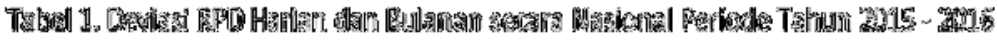

\begin{tabular}{|c|c|c|c|c|c|c|c|c|c|c|c|c|c|}
\hline & & 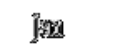 & Ho & 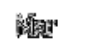 & swe & 嗮形 & Wha & ind & 数慗 & 羟西 & Wh & 物经 & Mot: \\
\hline 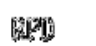 & $2 \pi{ }^{2}$ & $100 \%$ & 1009 & iog & $106 \%$ & 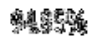 & 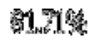 & 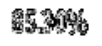 & 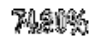 & 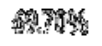 & 7954 & 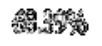 & 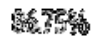 \\
\hline Fxth & 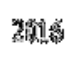 & ngs & 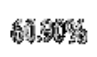 & âlos & 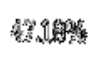 & 6) & 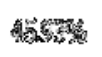 & 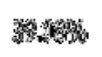 & 3hIn & 到紫1 & 30 & 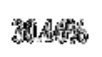 & W \\
\hline SELt: & 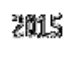 & 17. & 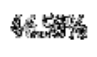 & 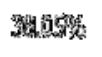 & 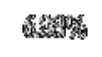 & 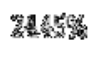 & $146 x^{2}$ & 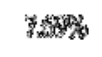 & 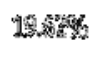 & 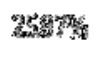 & 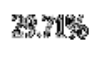 & 6, & 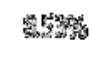 \\
\hline Oadmen & ริดิ & 13 and & 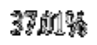 & 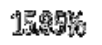 & WETH & 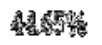 & 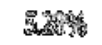 & 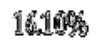 & 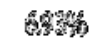 & 3 & 34. & 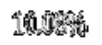 & 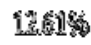 \\
\hline
\end{tabular}

Sumber: Steven, Analisis Efektivitas Penerapan Perencanaan Kas Pemerintah Pusat $(2017,7)$

${ }^{1}$ Benchmark penyusunan proyeksi arus kas mengacu pada negara New Zealand, Australia, Perancis dan beberapa negara Eropa lainnya. 
deviasi paling rendah terjadi pada pertengahan semester kedua tahun 2016.

Tingginya tingkat deviasi data RPD Harian maupun RPD Bulanan yang disampaikan oleh satker tentunya akan berpengaruh terhadap kualitas perencanaan kas pemerintah. Hal ini dikarenakan perencanaan kas disusun berdasarkan akumulasi data RPD Harian, RPD Bulanan, RPnD, maupun Proyeksi Penerimaan dan Pengeluaran eselon I Kementerian Keuangan.

Berangkat dari hal-hal tersebut, penulis beranggapan bahwa perlu dilakukan evaluasi terhadap mekanisme penyusunan proyeksi arus kas pemerintah yang dapat menjawab pertanyaan riset: Apakah Pemerintah Pusat menerapkan mekanisme penyusunan cash flow forecasting sesuai dengan frameworkmaupun best practice internasional?

Mempertimbangkan latar belakang tersebut, penulis berharap penelitian ini dapat bermanfaat untuk membantu Kementerian Keuangan c.q. DJPb meningkatkan peran proyeksi arus kas dalam rangka manajemen kas pemerintah.

\subsection{Penelitian Sebelumnya}

Di Indonesia, sudah banyak penelitian yang membahas masalah terkait perencanaan kas pemerintah. Akan tetapi, mayoritas penulis meneliti mengenai efektivitas pelaksanaan perencanaan kas. Misalnya seperti Bagaskoro (2016) yang melakukan analisis faktor yang mempengaruhi efektivitas perencanaan kas tingkat satker lingkup KPPN Jakarta III. Hasibuan (2016) selain meneliti hal yang sama, juga mengukur tingkat efektivitas perencanaan kas lingkup KPPN Jakarta II. Bagaskoro dan Hasibuan melakukan penelitian studi kasus dengan menyebarkan kuesioner kepada satker mitra kerja masing-masing KPPN.

Selain itu, terdapat penelitian dari Muthohar (2012) yang juga melakukan studi kasus untuk menentukan faktor efektivitas perencanaan kas. Bedanya, Muthohar menggunakan metode yang lebih mutakhir, yaitu dengan penggunaan metode Structural Equation Modelling (SEM) berbasiskan variance (Partial Least Square). Sementara itu, Steven (2017) mengukur tingkat efektivitas perencanaan kas Pemerintah Pusat di Direktorat PKN. Apa yang dibahas oleh Steven memiliki lingkup yang lebih luas karena tidak hanya membahas tentang RPD, tetapi juga RPnD, serta proyeksi penerimaan dan pengeluaran negara dari unit eselon I lingkupKementerian Keuangan.

Terdapat pula beberapa penulis yang membahas aspek-aspek lain dari perencanaan kas di Indonesia. Misalnya Huda (2010) membahas tentang kajian yuridis RPD dalam DIPA. Septiawan (2016) memanfaatkan data mining untuk mencari atribut apa saja yang mendukung tingkat akurasi RPD pada satker. Seftianova dan Adam (2013) mencari pengaruh perencanaan kas terhadap penyerapan anggaran.

Meskipun begitu, belum banyak tulisan yang membahas terkait evaluasi pelaksanaan perencanaan kas.Haryanto dan Wihascaryo (2011) melakukan evaluasi terhadap pelaksanaan perencanaan kas namun hanya pada tingkat satker dengan studi kasus pada KPPN Jakarta II. Kemudian ada pula Alfiah (2016) yang melakukan studi yang sama pada KPPN Padang. Lebih lanjut lagi, sepengetahuan penulis belum ada penelitian yang membahas secara spesifik tentang evaluasi mekanisme penyusunan perencanaan kas Pemerintah Pusat. Dengan demikian, masih terdapat celah riset terkait dengan hal ini yang dapat terus digali. Penulis berharap bahwa tulisan ini dapat berkontribusi untuk mengisi celah riset tersebut.

\section{KERANGKA TEORI}

\subsection{Perencanaan Kas Pemerintah}

Menurut PMK 197 tahun 2017, Perencanaan Kas Pemerintah Pusat merupakan suatu nilai hasil akumulasi dari RPD, RPnD, dan Proyeksi Penerimaan dan/atau Pengeluaran unit eselon I Kementerian Keuangan. Perencanaan kas yang akurat merupakan hal yang sangat penting di dalam manajemen kas karena menjadi dasar bagi pengelola kas dalam menggambarkan pola arus kas organisasi untuk memitigasi kebutuhan kas, meyakinkan pembayaran disusun secara terjadwal dan membantu dalam pengambilan tindakan untuk mencari sumber-sumber pembiayaan yang efisien serta mengoptimalkan kelebihan kas yang mengendap(idle cash) untuk mendapatkan tingkat pengembalian yang baik.

Perencanaan kas merupakan salah satu kunci yang menentukan keberhasilan pengelolaan kas dalam suatu organisasi baik organisasi publik maupun organisasi privat. Efektivitas pengelolaan kas membutuhkan perencanaan arus kas jangka pendek yang akurat dan tepat waktu (Lienert 2009, 7). Hal ini senada dengan apa yang disampaikan Murwanto, Insyafiah, dan Subkhan (2006, 155) bahwa tujuan utama dari perencanaan kas adalah untuk memberikan pedoman yang cukup dan tepat waktu dalam rangka menentukan tindakan untuk mencapai pengendalian yang baik atas arus kas organisasi.

Perencanaan kas itu sendiri, sesuai dengan amanat PMK 197 Tahun 2017, disusun dengan mengacu pada data yang bersumber dari RPD Harian, RPD Bulanan, RPnD tingkat nasional, dan Proyeksi pengeluaran dan/atau penerimaan dari Unit Eselon I Kementerian Keuangan (seperti diilustrasikan dalam Gambar 1). 
42

Gambar 1. Sumber Data Perencanaan Kas Pemerintah Pusat

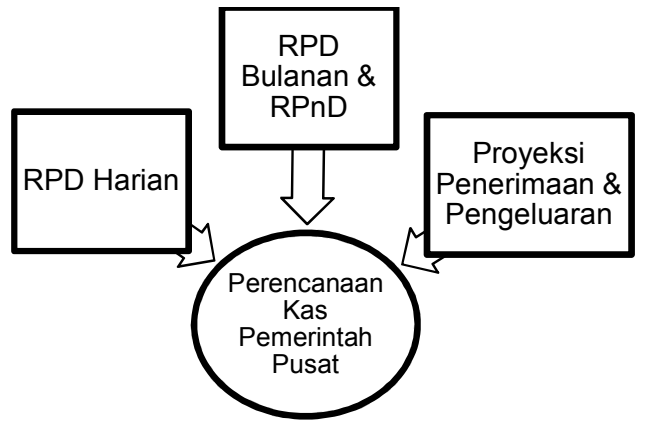

Sumber: Steven, 2017

\subsection{Cash Forecasting Framework}

Untuk dapat mewujudkan fungsi perencanaan kas, pemerintah baik tingkat pusat maupun kantor vertikal di daerah perlu menyusun proyeksi perencanaan penarikan dan penerimaan dana dengan mengedepankan perkiraan yang wajar (Government Finance Officers Association (GFOA), 2011). Proyeksi tersebut, sekaligus dengan berbagai pertimbangan, metodologi, dan asumsi yang dipakai, sebaiknya di sampaikan dengan jelas kepada semua stakeholders. GFOA (2014) memformulasikan beberapa langkah kunci yang dapat digunakan sebagai panduan (framework) penyusunan proyeksi penarikan dan penerimaan tersebut (seperti diilustrasikan pada Gambar 2). Framework tersebut dapat diuraikan sbb:

\section{Defining assumptions}

Langkah pertama dalam penyusunan proyeksi arus kas dimulai dengan menentukan halhal fundamental yang mungkin dapat mempengaruhi hasil perkiraan. Hasil dari langkah ini akan memberikan gambaran mengenai metode penyusunan proyeksi arus kas apa yang paling tepat. Selain itu, langkah ini juga akan memberikan pemahaman yang seragam antar-stakeholders mengenai tujuan proses penyusunan proyeksi.

Dalam langkah ini, terdapat empat pertanyaan kunci yang dapat diperhatikan pada saat proses penyusunan proyeksi: i) Seperti apa time horizon dari proyeksi arus kas? ii) Apa saja tujuan dari kebijakan proyeksi arus kas pemerintah? iii) Apa saja isu politik yang berkaitan dengan proyeksi arus kas? iv) Apa saja jenis penerimaan dan pengeluaran yang menjadi perhatian utama pemerintah?

\section{Gathering information}

Untuk menghasilkan proyeksi kas yang akurat, GFOA merekomendasikan kombinasi penggunaan data statistik maupun pertimbangan profesional dari penyusun proyeksi. Dengan demikian, proses pengumpulan informasi yang diperlukan untuk penyusunan proyeksi merupakan hal yang krusial. Keakuratan informasi rencana pengeluaran dan penerimaan unit terkecil pemerintah (subsidiary/municipalities), dan jugaupdate atas informasi tersebut akan menentukan keakuratan hasil proyeksi arus kas nasional.

Langkah gathering information didesain untuk meningkatkan awareness dan wawasan penyusun proyeksi arus kas terkait hal-hal apa saja yang berpengaruh terhadap pendapatan maupun belanja. Para penyusun proyeksi juga harus aware akan kejadian-kejadian yang dapat menyebabkan bergesernya trend dan asumsi yang digunakan.

\section{Preliminary/exploratory analysis}

Pada langkah selanjutnya, penyusun proyeksi perlu untuk melakukan analisis terkait data historis dan kondisi ekonomi yang mungkin dapat berpengaruh pada hasil perencanaan kas. Beberapa pertanyaan yang perlu dijawab oleh penyusun proyeksi terkait penggunaan data historis dalam perencanaan kas, diantaranya:

a. Seperti apa cash inflow dan cash outflow selama beberapa tahun sebelumnya?

b. Apa saja sumber pembiayaan selama beberapa tahun sebelumnya?

Langkah preliminary/exploratory analysis ini akan membantu dalam hal pemilihan metode penyusunan proyeksi pada tahun selanjutnya. Proses analisis dapat dilakukan dengan mempelajari berbagai pola dan trend yang ada pada data historis. Secara umum, penyusun proyeksi dapat memperhatikan hal-hal yang berhubungan dengan business cycles, demographic trends, maupun outliers and historical anomalies.

4. Selecting and implementing methods

Langkah selecting and implementing methods terdiri dari proses pertimbangan penentuan metode yang akan digunakan untuk menghasilkan proyeksi arus kas. Penyusun proyeksi dapat memilih antara metode kuantitatif maupun kualitatif. Penyusun proyeksi dapat memilih metode yang berbeda untuk masing-masing jenis belanja dan penerimaan. Terdapat tiga model dasar penyusunan proyeksi arus kas: i) ekstrapolasi, ii) regresi/ekonometrik, dan iii) metode hibrida.

\section{Gambar 2. Skema GFOA Forecasting Framework}

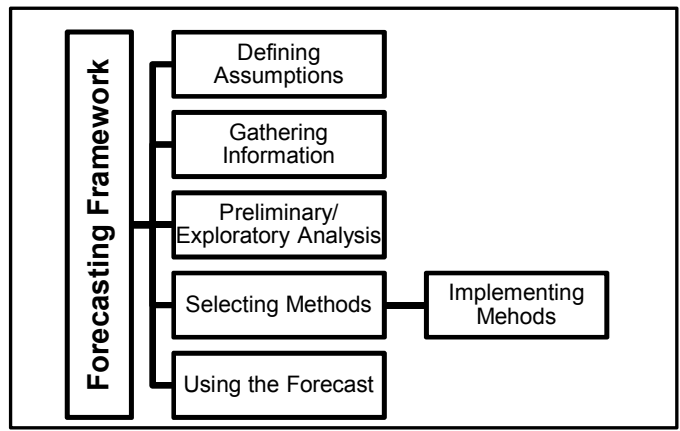

Sumber: Diolah GFOA, 2012

Selanjutnya, pemerintah dapat melakukan 
penyusunan proyeksi arus kas dengan menerapkan satu atau beberapa teknik forecasting. Bila diperlukan, penyusun proyeksi dapat mengembangkan suatu kisaran hasil perkiraan berdasarkan beberapa skenario yang berbeda.

\section{Using Forecast}

Perencanaan kas yang bermanfaat adalah perencanaan kas yang dapat berguna untuk membantu dalam proses pengambilan keputusan. Untuk itu, hasil proyeksi arus kas haruslah dapat disampaikan seinformatif mungkin. Tiga hal yang sangat berpengaruh terhadap predictive value dari proyeksi arus kas adalah:

a. kredibilitas para penyusun proyeksi arus kas;

b. penyampaian hasil proyeksi arus kas yang jelas dan informative; dan

c. menghubungkan hasil proyeksi kas dengan pengambilan keputusan.

\section{METODOLOGI PENELITIAN}

Berdasarkan taraf dan tujuan penelitian, jenis penelitian ini termasuk ke dalam penelitian deskriptif dengan model analisis bersifat evaluasi. Sementara itu, penulis menggunakan pendekatan metodologi kualitatif untuk menjawab pertanyaan penelitian. Penelitian dilakukan pada objek yang alamiah, yaitu objek yang berkembang apa adanya, tidak dimanipulasi, dan kehadiran peneliti tidak mempengaruhi dinamika pada objek tersebut. Dengan demikian, penelitian ini melaporkan pandangan terinci dari informan secara objektif apa adanya.

\subsection{Objek Penelitian}

Objek penelitian dalam tulisan ini adalah mekanisme penyusunan RPD Harian, RPD Bulanan, RPnD, Proyeksi Penerimaan dan Pengeluaran Negara sebagai dasar penyusunan Perencanaan Kas Pemerintah Pusat yang dilakukan oleh satker lingkup KPPN Jakarta II, Unit Eselon I Kemenkeu, Direktorat Pelaksanaan Anggaran (Direktorat PA), dan Direktorat PKNperiode tahun anggaran 2015 dan 2016

Dalam penelitian ini, evaluasi terhadap objek penelitian dilakukan dengan berdasar pada framework best practice proyeksi arus kas yang diterbitkan oleh GFOA (Government Finance Officers Association). GFOA yang terbentuk sejak tahun 1906 merupakan representasi public finance officials dari seluruh wilayah Amerika Serikat dan Kanada. Anggota GFOA meliputi pemerintah federal, pemerintah negara bagian, maupun local government. Tugas dan fungsi GFOA terdiri dari perencanaan, pembiayaan, maupun implementasi kegiatan operasional di bidang finansial. Selain itu, GFOA juga menyediakan berbagai pedoman best practice, konsultasi, recognition programs, maupun publikasi seperti buku, $e$-book, dan riset.
Penulis menilai framework GFOA tentang penyusunan proyeksi arus kas yang di-release pada tahun 2014 dapat dijadikan sebagai alat ukur evaluasi yang up to date. Berbagai elemen best practice tersebut juga sudah mempertimbangkan adanya subsidiaries/municipalities sehingga cocok dengan struktur organisasi pemerintah pusat. Selain itu, framework GFOA yang merupakan forecastingbest practice di Amerika Serikat dan Kanada akan menyediakan sudut pandang baru atas benchmark penyusunan proyeksi arus kas di Indonesia yang selama ini hanya mengacu pada Australia, New Zealand, dan negara-negara di benua Eropa.

\subsection{Sumber Data dan Teknik Pengumpulan Data}

Dalam penelitian ini, teknik pengumpulan data dilakukan melalui metode penelitian kepustakaan dan wawancara. Berdasarkan sumbernya, jenis data yang digunakan dalam penelitian ini meliputi data primer dan data sekunder. Penulis mendapatkan data primer melalui wawancara mendalam secara langsung kepada informan yang terdiri dari berbagai pihak yang terlibat langsung di dalam proses penyusunan perencanaan kas Pemerintah Pusat dan juga pengamat/akademisi. Dengan kata lain, informan terdiri dari pihak regulator, operator, dan pengamat eksternal.

Selain itu, data sekunder yang digunakan dalam penelitian ini diantaranya: i) Peraturan terkait perencanaan kas; ii) Data Perencanaan Kas Pemerintah Pusat tahun 2015 dan 2016 yang diperoleh dari Direktorat PKN; iii) Data RPD Harian tahun 2015 dan 2016 yang diperoleh dari KPPN Jakarta II; dan iv) Hasil penelitian sebelumnya.

Proses coding transcript maupun pengolahan data wawancara dilakukan dengan bantuan program MicrosoftOffice Excel dan NVivo 12-free trial. Pengujian keabsahan data penelitian dilakukan dengan uji kredibilitas, uji transferability, uji dependability, maupun uji confirmability.

\section{HASIL PENELITIAN}

Pada sub-bab ini akan disajikan pembahasan evaluasi mekanisme penyusunan perencanaan kas Pemerintah Pusat berdasarkan forecasting framework yang diterbitkan oleh GFOA.

\subsection{Defining Assumptions}

GFOA merekomendasikan bahwa pemerintah sebaiknya memulai proses penyusunan proyeksi arus kas dengan mendefinisikan dan memetakan isu-isu fundamental yang mungkin berpengaruh terhadap kas pemerintah. Isu-isu tersebut misalnya mengenai tujuan dan prioritas kebijakan perencanaan kas pemerintah, time horizon, politik dan hukum, serta apa saja major revenue and expenditure categories. 
a. Tujuan dan Prioritas Perencanaan Kas

Penentuan tujuan/objective dari penyusunan proyeksi arus kas dinilai oleh GFOA sebagai hal yang penting dan menjadi salah satu hal yang harus dilakukan pemerintah di tahap awal formulasi mekanisme perencanaan kas. Bila arah visi, tujuan dan prioritas telah jelas, maka berbagai langkah teknis berikutnya dapat disusun dan dikembangkan sebagaimana mestinya. Williams $(2009,3)$ telah mengumpulkan dan mengklasifikasikan tujuan penyusunan proyeksi arus kas dari berbagai negara maju, sebagai berikut: ${ }^{2}$

1. untuk memfasilitasi usaha pencapaian target kebijakan finansial dan memastikan bahwa belanja yang telah direncanakan dalam anggaran dapat dibiayai dengan cukup dan tepat waktu;

2. untuk merencanakan strategi supaya dapat memperbaiki profil arus kas, meminimalisasi idle cash, dan mengurangi borrowing cost; dan

3. untuk turut berkontribusi dalam implementasi kebijakan moneter.

Sementara itu, tujuan perencanaan kas di Indonesia sebagaimana tertuang dalam PMK 197 tahun 2017 adalah: (i) memperbaiki informasi RPD dan RPnD yang tercantum dalam DIPA; (ii) memperbaiki Rencana Pelaksanaan Kegiatan untuk mendukung pencapaian target kinerja; (iii) memberikan informasi bagi BUN/Kuasa BUN untuk pengelolaan likuiditas; dan (iv) memberikan sumber informasi mengenai target penerimaan dan meningkatkan kepastian atas tercapainya target penerimaan tersebut.

Pemerintah Indonesia sampai saat ini masih kurang mengakui peran proyeksi arus kas bagi pelaksanaan kebijakan moneter. Pembahasan mengenai hal ini juga tidak dapat ditemukan dalam PMK Tahun 2017 maupun penjelasannya. Padahal selain Williams, berbagai ahli seperti Mu $(2006,11)$ maupun Potter dan Diamond dalam Muthohar $(2012$, 4) sepakat menyampaikan adanya kontribusi nyata perencanaan kas terhadap kebijakan moneter.

Adanya proyeksi arus kas yang akurat akan menurunkan tingkat volatilitas saldo kas yang seringkali menjadi penghambat penerapan kebijakan moneterWilliams $(2009,4)$. Di lain sisi, kemampuan untuk memproyeksikan cash inflow dan cash outflow akan membuka kemungkinan bagi pemerintah untuk mengelola saldo kas dan excess cash secara lebih akurat. Pemanfaatan excess cash ini di pasar domestik tentu akan mempengaruhi jumlah uang beredar yang merupakan domain kebijakan moneter.

Dengan demikian, RPD Harian, RPD Bulanan, dan RPnD meskipun diatur dalam peraturan yang sama dan memiliki tujuan yang sama, tetapi latar

${ }^{2}$ Developed countries yang menjadi objek penelitian Williams (2009) diantaranya Australia, UK, Perancis, USA, dan Kanada. memiliki belakang berbeda. Dalam wawancara yang telah dilakukan, regulator RPD Bulanan menyebutkan bahwa pengaturan RPD Harian dan RPD Bulanan disatukan dalam rangka penyederhanaan. Akan tetapi, latar belakang penyusunan RPD Bulanan lebih kepada pengedukasian satker dalam hal perencanaan kegiatan. Bila sudah dapat merencanakan kegiatan dengan baik, maka diharapkan satker akan semakin akurat dalam melakukan penyusunan proyeksi RPD. Bila tingkat akurasi satker sudah baik, maka ujungnya akan membantu BUN dalam pengelolaan likuiditas kas pemerintah.

RPD Harian dibutuhkan dalam rangka perencanaan penerimaan dan pengeluaran pemerintah. Dengan adanya perencanaan tersebut, pemerintah dalam hal ini BUN akan dapat memprediksi posisi kas pada suatu periode tertentu. Dengan berbekal informasi tersebut, maka BUN kemudian dapat memprediksi apakah posisi kas pemerintah cukup untuk membiayai pengeluaran.

Dengan demikian, prioritas penyusunan RPD Harianadalah untuk menjamin likuiditas kas pemerintah. Maka, penyusunan perencanaan kas di Direktorat PKN dilakukan untuk menjamin terpenuhinya kebutuhan kas pemerintah. Baru kemudian bila terdapat surplus, pemerintah dapat melakukan optimalisasi kas. Sementara itu, fokus penyusunan RPD Bulanan adalah untuk membantu satker merencanakan kegiatan sehingga diharapkan akan dapat memperbaiki informasi perencanaan kas di Halaman III DIPA.

GFOA menekankan bahwa pemerintah seharusnya menyampaikan secara transparan perihal tujuan, prioritas, maupun asumsi kebijakan perencanaan kas kepada semua stakeholders. Dengan demikian, berbagai pihak yang bertanggung jawab dalam penyusunan proyeksi arus kas di sepanjang hierarki kepemerintahan bisa paham betul mengenai sudut pandang pemerintah terkait kebijakan perencanaan kas.Dengan demikian, para penyusun proyeksi arus kas dapat menggunakan asumsi yang tepat dan memilih metode yang paling sesuai.

Permasalahannya, SDM pada satker sampai sekarang dinilai belum begitu memahami apa yang diinginkan oleh Pemerintah Pusat terkait kebijakan perencanaan kas. Hal ini disampaikan oleh Subagio selaku pengamat dan akademisi PKN STAN. Satker belum paham betul apa itu peran perencanaan kas sehingga beranggapan bahwa perencanaan kas hanyalah untuk memenuhi kepentingan sektoral BUN. 


\section{b. Time Horizon Perencanaan Kas}

Time horizon/forecast horizon menggambarkan batas waktu seberapa jauh suatu proyeksi harus dibuat untuk periode di masa depan. Time horizon biasanya merupakan jangka periode untuk suatu siklus proyeksi. Siklus proyeksi dapat dibuat untuk berbagai time frame yang berbeda, misalnya satu bulan, satu semester, satu tahun, bahkan sampai lebih dari tiga tahun. Time horizon ini sedikit banyak terkait dengan elemen timeliness dari proyeksi arus kas. Efeknya, time period yang berbeda akan memerlukan perlakukan forecasting yang berbeda pula.

Tidak ada formulasi pasti untuk menentukan seberapa panjang forecast horizon yang sesuai untuk suatu negara. Praktik pada negara-negara internasional juga tidak menyediakan guidance yang jelas karena masing-masing negara memiliki kondisi yang berbeda (Williams 2009, 3). Tetapisecara umum, proyeksi arus kas akan dibuat secara tahunan/annual yang selanjutnya dikonversi secara lebih detail menjadi profil proyeksi bulanan maupun harian.

Di Amerika Serikat misalnya, US Department of Treasury mengelola proyeksi arus kasdari setiap agensi di pemerintah federal untuk 12 (dua belas) bulan ke depan. Cash flow projection ini terus menerus di-update secara triwulanan berdasarkan informasi yang didapatkan dari Agency Budget Offices. Informasi yang dikirim oleh Agency Budget Offices menyediakan estimasi total pengeluaran secara bulanan untuk berbagai program, kegiatan, maupun untuk setiap rekening yang dimiliki oleh pemerintah.

Di Indonesia, satker diwajibkan untuk menyusun RPD untuk satu tahun anggaran yang dimuat dalam Halaman III DIPA. RPD tersebut dibuat secara bulanan mulai dari bulan Januari sampai dengan Desember. Selain dalam bentuk bulanan, satker juga menyusun RPD dalam bentuk harian. Data proyeksi secara harian ini diperlukan karena memang pembayaran tagihan pemerintah dilakukan secara harian. Hal ini sesuai dengan objektif penyusunan perencanaan kas menurut Williams $(2004,27)$ yaitu untuk menghasilkan proyeksi cash inflow dan cash outflow secara harian selama suatuperiode di masa yang akan datang. Williams kemudian merekomendasikan periode proyeksi arus kas tersebut sebaiknya disusun untuk jangka waktu minimal satu bulan ke depan. ${ }^{3}$ Walaupun, Williams menambahkan bahwa idealnya periode ini seharusnya tidak kurang dari tiga bulan.

IMF (International Monetary Fund) selaku konsultan penyusunan perencanaan kas

${ }^{3}$ Beberapa negara menyusun proyeksi arus kas secara harian untuk periode satu tahun ke depan, misalnya Perancis. Lihat Williams $(2004,27)$.
Pemerintah Pusat merekomendasikan agar penyusunan proyeksi arus kas harian sebaiknya dilakukan untuk periode sampai tiga bulan ke depan. Namun demikian, Pemerintah Indonesia belum dapat memenuhi rekomendasi tersebut.

Sebagaiamana diatur dalam PMK 197 tahun 2017, batas penyampaian RPD Harian paling lama adalah 15 hari kerja sebelum penyampaian SPM. Batas penyampaian maksimal lima belas hari kerja ini berlaku untuk seluruh tipe Transaksi A yang memiliki nilai kotor lebih dari satu triliun rupiah. Sedangkan untuk tipe Transaksi B dan Transaksi C, batas penyampaian RPD Harian lebih singkat lagi yaitu masing-masing sepuluh dan lima hari kerja. Pembagian tipe transaksi dan batas penyampaian RPD Harian dapat dilihat pada Tabel 2.

Tabel 2. Klasifikasi Transaksi dan Batas Penyampaian RPD Harian

\begin{tabular}{|c|c|c|c|}
\hline $\begin{array}{l}\text { JenisTran } \\
\text { saksi }\end{array}$ & $\begin{array}{l}\text { Nilai } \\
\text { SPM }\end{array}$ & $\begin{array}{l}\text { Batas } \\
\text { Penyampaian }\end{array}$ & $\begin{array}{l}\text { Batas } U p \\
\text { dating }\end{array}$ \\
\hline Tipe A & $>1 \mathrm{~T}$ & 15 hari & 10 hari \\
\hline Tipe B & $500 \mathrm{M}-1 \mathrm{~T}$ & 10 hari & 5 hari \\
\hline Tipe C & 1M-500M & 5 hari & - \\
\hline
\end{tabular}

Sumber: Diolah dari PMK 197 tahun 2017

Time frame proyeksi arus kas yang terlalu pendek rawan terhadap uncertainty sehingga meningkatkan risiko likuiditas. Jika terjadi shortfall, maka pemerintah hanya memiliki waktu yang singkat untuk menyiapkan alternatif pembiayaan. Apalagi bila menilik kondisi tingkat kedalaman pasar keuangan Indonesia yang masih dangkal, maka pemerintah memiliki alternatif kebijakan pembiayaan yang sangat terbatas (Suselo, Soekro dan Nugraha 2013, 4).4

c. Isu Politik dan Hukum

Subagio mengatakan bahwa isu politik sebenarnya kurang begitu dekat dengan perencanaan kas di Indonesia. Hal ini terkait dengan fungsi pemerintah yang hanya melakukan pengaturan saja mengenai besaran kas yang masuk dan yang keluar dari Rekening Kas Umum Negara(RKUN). Sehingga menurutnya, isu politik lebih banyak berada di DPR yang menjalankan fungsi legislatif.

Namun demikian, isu politik cukup rentan terjadi bila penerimaan mengalami shortfall. Bila penerimaan shortfall, maka perencanaan kas harus ditekan dan dapat mengakibatkan pemerintah melakukan efisiensi dan penghematan. Penghematan seperti ini berisiko menghambat pelaksanaan pelayanan publik. Selain itu, penghematan anggaran jugamenghalangi

4 Tingkat kedalaman pasar keuangan Indonesia walaupun telah berkembang, tetapi masih jauh tertinggal bila dibandingkan dengan Malaysia, Thailand, apalagi dengan Singapura. Lihat Suselo, Soekro dan Nugraha $(2013,43)$ 
46

berjalannya fungsi APBN sebagai stimulus fiskal dan pendorong perekonomian. Hal ini sangat disayangkan karena pengeluaran pemerintah berpengaruh secara signifikan terhadap pertumbuhan ekonomi Indonesia (Swaramarinda dan Indriani 2011, 98). Pada akhirnya, hal ini berdampak pada citra dan kinerja pemerintah di bidang perekonomian.

Di lain sisi, adanya shortfall penerimaan dan rendahnya akurasi perencanaan kas berimbas pada kebutuhan pembiayaan yang tinggi. Pembiayaan dalam bentuk penerbitan surat utang menjadi alternatif pertama sebelum pemerintah melakukan penghematan ataupun pemotongan anggaran. Namun demikian, pemerintah dalam melakukan pembiayaan bukan tanpa batas. Undang-undang Nomor 17 tahun 2013 tentang Keuangan Negara mengamanatkan batas maksimal defisit APBN adalah 3 persen dari PDB sedangkan batas maksimal hutang pemerintah adalah 60 persen dari PDB. Batas-batas inilah yang selalu dijaga oleh pengelola kas karena bila batas ini terlewati, dapatmenimbulkan dampak politik.

\section{d. Major Revenues and Expenditure Categories}

GFOA merekomendasikan kepada setiap level hierarki kepemerintahan untuk menentukan jenis penerimaan maupun belanja yang utama dan memerlukan perhatian lebih. Dengan melakukan hal ini, pemerintah akan dapat mengevaluasi risiko finansial dan dapat lebih memperhitungkan alternatif pembiayaan bila terjadi shortfall. Tabel 3 menunjukkan daftar major revenues dan expenditures yang direkomendasikan GFOA.

Jenis penerimaan pajak yang menjadi fokus Direktorat Jenderal Pajak (DJP) adalah Pajak Penghasilan (PPh) Non-migas dan Pajak Pertambahan Nilai (PPN). Jenis pajak ini dipilih karena disamping jumlahnya yang dominan, detil data tambahan penerimaan juga lebih clear dan dapatdipisahkan dari penerimaan yang nonrutin,sehingga secara teknis, lebih mudah untuk dilakukan modelling. Sementara itu, regulator RPD pada Direktorat PKN menyampaikan bahwa jenis pengeluaran yang menjadi perhatian dalam perencanaan kas adalah belanja yang bernilai besar (dalam hal ini, belanja yang bernilai besar biasanya termasuk dalam klasifikasi jenis belanja modal).

\begin{tabular}{l|c}
\hline \multicolumn{2}{l}{ Tabel 3. Major Revenues and Expenditures } \\
\hline Major Revenues & Major Expenditures \\
\hline - Taxes & - General government \\
- Grant in lieu of taxes & services \\
- Services provided to & - Protective services \\
other governments & - Transportation \\
- Sales of services & services \\
- Other revenue from & - Environmental \\
own sources & health services \\
- Unconditional & - Public health and \\
transfers from other & welfare services \\
governments & - Enviromental \\
- Conditional transfers & development \\
from other & services \\
governments & - Recreation and \\
- Other transfers from & cultural services \\
other government & - Fiscal services \\
\hline
\end{tabular}
Sumber: GFOA, Financial Forecasting: Budget Preparation \& CFF(2013)

Kemudian, belanja lain yang perlu mendapat perhatian khusus oleh Direktorat PKN adalah belanja yang menjadi concern/perhatian pimpinan, seperti misalnya Dana Transfer Daerah, DAK Fisik, maupun Dana Desa. Direktorat PKN juga membuat proyeksi secara detail belanja-belanja yang menjadi isu nasional seperti pembayaran gaji ketigabelas dan Tunjangan Hari Raya (THR), dan kenaikan gaji PNS.

Data rekapitulasi pengiriman RPD Harian di KPPN Jakarta II pada tahun 2015 dan 2016 mendukung informasiyang disampaikan para informan. ${ }^{5}$ Belanja modal (BAS 53) memiliki ratarata nilai transaksi yang lebih besar jikadibandingkan dengan belanja pegawai (BAS 51) maupunbelanja barang dan jasa (BAS 52). Gambar 3 menggambarkan perbandingan nilai transaksi RPD Harian untuk belanja pegawai, belanja barang dan jasa, dan belanja modal.

\section{Gambar 3. Perbandingan Rata-rata Nilai Transaksi RPD Harian di KPPN Jakarta II}

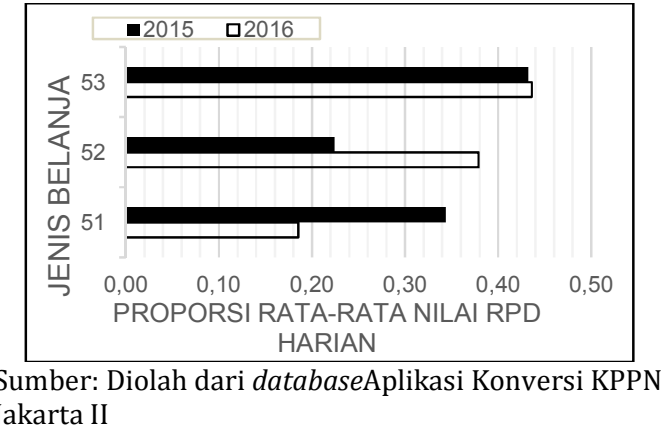

Namun demikian, jenis belanja dengan jumlah pengiriman RPD Harian paling banyak adalah belanja barang dan jasa. Volume pengiriman

${ }^{5} \mathrm{KPPN}$ Jakarta II mengelola pagu satker dengan nilai paling besar se-Indonesia. KPPN Jakarta II juga merupakan mitra kerja satkersatker pengelola anggaran BUN. 
RPD Harian di KPPN Jakarta II untuk belanja barang dan jasa pada tahun 2015 dan 2016 melebihi 1.000 transaksi (Gambar 4 menggambarkan jumlah pengiriman RPD Harian dengan lebih detail). Hal ini menunjukkan bahwa belanja barang dan jasa sangat berpengaruh pada akurasi proyeksi arus kas. Oleh karena itu, penyusun proyeksi sebaiknya juga menaruh perhatian lebih pada belanja barang dan jasa untuk menjaga deviasi proyeksi pada tingkat toleransi.

\section{Gambar 4. Pengiriman RPD Harian per Jenis Belanja di KPPN Jakarta II}

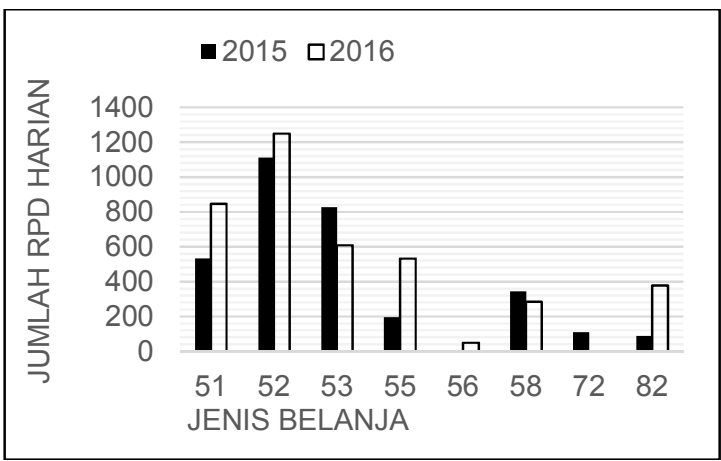

Sumber: Diolah dari database Aplikasi Konversi KPPN Jakarta II

\subsection{Gathering Information}

Menurut GFOA, proses penyusunan proyeksi arus kas yang efisien membutuhkan berbagai data yang reliable, memadai, dan relevan. Hal ini merupakan fondasi bagi pelaksanaan fungsi proyeksi arus kas supaya dapat membantu proses pengambilan keputusan. Dengan demikian, penggunaan informasi yang keliru akan menimbulkan efek negatif pada pelaksanaan fungsi tersebut.

Secara umum, terdapat dua pendekatan dalam menyusun model cash forecasting pemerintah jika dilihat dari informasi yang digunakan (Williams 2010, 4). Kedua pendekatan tersebut adalah pendekatan top-down dan bottomup. Pendekatan top-down menggunakan informasi yang dimiliki pengelola kas, yaitu berupa data historis yang tersimpan dalam basis data. Di lain sisi, pendekatan bottom-up memanfaatkan informasi yang disampaikan oleh instansi pemerintah (misalnya instansi vertikal di daerah) kepada pengelola kas pusat. Informasi dari satker ini sangatlah berharga karena biasanya satker lebih dekat dan lebih paham setiap transaksi yang dilakukan daripada pengelola kas di pusat.

Pada pendekatan bottom-up, para pengelola kas dihadapkan pada permasalahan mendapatkan akses pada informasi yang tidak hanya cukup dan akurat, namun juga tepat waktu. Informasi memang sebaiknya dapat diperoleh secara timely supaya dapat digunakan seefektif mungkin. Mengingat perencanaan kas memiliki relevansi yang kuat dengan memprediksi sesuatu yang akan terjadi, kecepatan penyampaian data untuk membuat perencanaan kas menjadi sangat penting. Hal ini dikarenakan, ketika kejadian tersebut telah menjadi kenyataan (direalisasikan), maka perencanaan kas tersebut tidak lagi berguna dan berubah fungsinya menjadi laporan realisasi anggaran (Tamba dan Wibawa 2008, 33). Kualitas/akurasi perencanaan kas akan semakin meningkat jika jarak pembuatan laporan dan waktu kejadian yang direncanakan semakin dekat. Gambar 5 menunjukkan bagaimana akurasi perencanaan kas dan kegunaan laporan meningkat seiring dengan semakin dekat saat kejadian.

Proses pengumpulan informasi yang akurat dan timely akan lebih sulit dilakukan bila struktur organisasi pemerintah terdiri dari banyak subsidiary/kantor daerah (Williams 2004, 28). Di Indonesia, permasalahan ini menjadi lebih serius karena wilayah geografis yang luas dan terpisah oleh zona waktu yang berbeda.Williams kemudian menyatakan bahwa tidak ada solusi mudah untuk dapat mengatasi permasalahan ini selain

Gambar 5. Tingkat Kegunaan Forecasting Berdasarkan Waktu Penyampaian

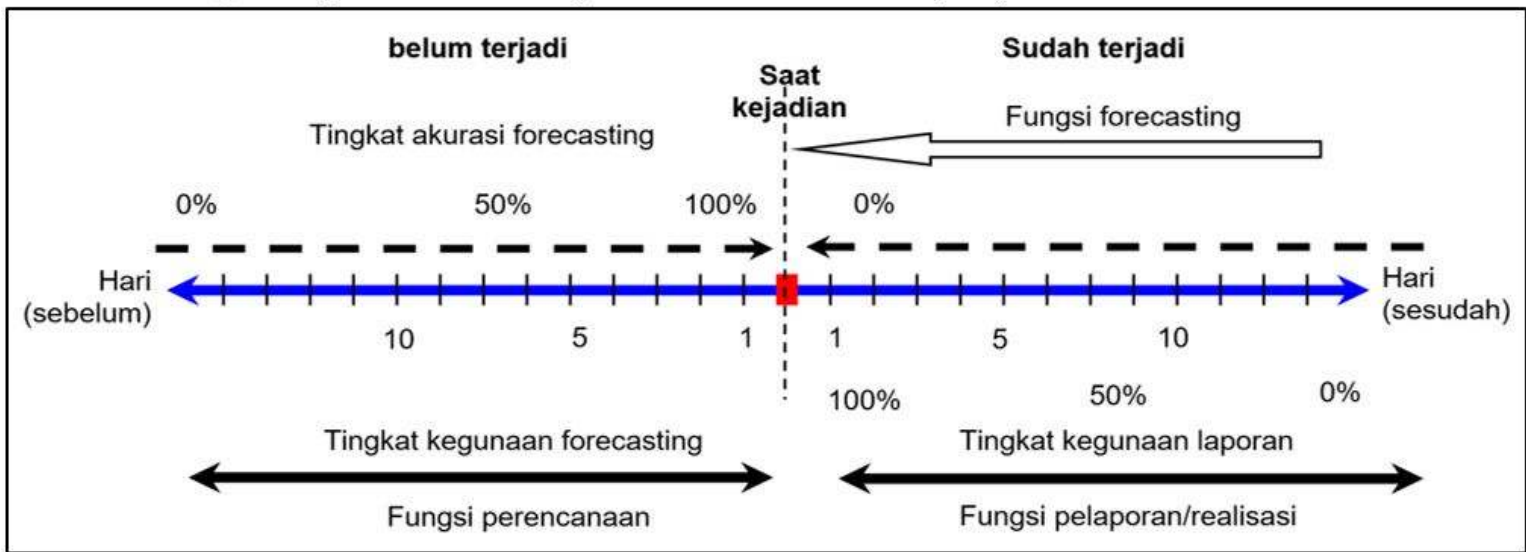

Sumber: Tamba dan Wibawa $(2008,33)$. 
memusatkan fokus pengumpulan data pada kementerian yang memiliki nilai transaksi besar. Di Inggris misalnya, pemerintah mendapatkan informasi proyeksi pengeluaran yang mendetail hanya dari 15 departemen yang memiliki belanja terbesar. ${ }^{6}$ Jikapemerintah Indonesia menerapkan kebijakan yang sama dengan di Inggris, maka K/L dengan pagu anggaran terbesar dapat dilihat pada Tabel 4. Dapat diperhatikan bahwa persebaran pagu belanja K/Ldi Indonesia sedikit lebih terkonsentrasi bila dibandingkan dengan pemerintah Inggris. Lebih dari $80 \%$ pagu belanja $\mathrm{K} / \mathrm{L}$ hanya dilaksanakan oleh $12 \mathrm{~K} / \mathrm{L}$ dari total lebih dari $60 \mathrm{~K} / \mathrm{L}$.

\begin{tabular}{|c|c|c|}
\hline $\begin{array}{l}\text { Kementerian } \\
\text { Negara/Lembaga }\end{array}$ & $\begin{array}{r}\text { \%APBN-P } \\
2016\end{array}$ & $\begin{array}{r}\text { \%RAPBN } \\
2017\end{array}$ \\
\hline $\begin{array}{l}\text {-Kementerian Pekerjaan } \\
\text { Umum }\end{array}$ & $13,8 \%$ & $12,8 \%$ \\
\hline -Kementerian Pertahanan & $13,6 \%$ & $14,3 \%$ \\
\hline -Polri & $9,4 \%$ & $10,5 \%$ \\
\hline -Kementerian Agama & $7,9 \%$ & $7,4 \%$ \\
\hline -Kementerian Kesehatan & $7,6 \%$ & $8,3 \%$ \\
\hline -Kemenhub & $6,3 \%$ & $5,7 \%$ \\
\hline -Kementerian Keuangan & $5,5 \%$ & $5,0 \%$ \\
\hline $\begin{array}{l}\text {-Kementerian Pendidikan } \\
\text { dan Kebudayaan }\end{array}$ & $5,2 \%$ & $5,7 \%$ \\
\hline $\begin{array}{l}\text {-Kementerian Ristek } \\
\text { Dikti }\end{array}$ & $5,1 \%$ & $5,4 \%$ \\
\hline -Kementerian Pertanian & $3,1 \%$ & $3,6 \%$ \\
\hline -Kementerian Sosial & $1,7 \%$ & $2,4 \%$ \\
\hline $\begin{array}{l}\text {-Kementerian Kelautan } \\
\text { dan Perikanan }\end{array}$ & $1,4 \%$ & $1,3 \%$ \\
\hline Total & $80,6 \%$ & $82,4 \%$ \\
\hline
\end{tabular}

Untungnya saat ini sudah banyak dikembangkan software/aplikasi yang dapat meringankan proses pengumpulan data yang dibutuhkan dalam perencanaan kas. DJPb c.q Direktorat PKN dan Direktorat PA sudah menguji coba dan mengimplementasikan berbagai aplikasi untuk membantu satker dalam hal penyusunan maupun pengiriman rencana penarikan dana. Secara umum, satker lebih banyak melakukan penyusunan RPD Harian menggunakan Sistem Aplikasi Satker (SAS). Sebenarnya selain SAS, Direktorat PKN telah melakukan piloting dan uji coba penggunaan aplikasi E-SPM maupun Sistem Aplikasi Keuangan Tingkat Instansi (SAKTI) yang dapat memudahkan satker karena miliki fitur pengiriman arsip data komputer (ADK) RPD secara online.

Adapun sumber informasi yang dibutuhkan oleh Direktorat PKN dalam rangka penyusunan

${ }^{6}$ Kelima belas departemen tersebut mewakili keseluruhan 47 departemen yang ada di Inggris dan memiliki jumlah pagu perencanaan kas sesuai PMK Nomor 197 tahun 2017 didapatkan dari berbagai pihak. Penyedia/supplier data untuk penyusunan perencanaan kas meliputi setiap unit yang mengelola pengeluaran maupun penerimaan negara yang terbagi di setiap level hierarki kepemerintahan. Dimulai dari unit paling kecil satker, unit tingkat Eselon 2, Eselon 1, dan tingkat K/L. Daftar sumber penyedia/supplier data tersebut dapat diperhatikan pada Tabel 5.

Tabel 5. Daftar supplier data untuk Penyusunan Perencanaan Kas

\begin{tabular}{ll}
\hline Data & Sumber \\
\hline RPD Harian & Satker - KPPN \\
\hline RPD Bulanan, Pemutakhiran & Satker - \\
RPD Bulanan & Kanwil - \\
& Direktorat PA \\
\hline Rencana Penerimaan Dana & Satker - \\
(RPnD), Pemutakhiran RPnD & Kanwil - \\
& Direktorat PA \\
\hline Proyeksi Pengeluaran & Unit Eselon I \\
dan/atau Proyeksi & Kementerian \\
Penerimaan Negara & Keuangan \\
\hline Sumber: Direktorat Pengelolaan Keuangan Negara, DJPb
\end{tabular}

Akan tetapi, fakta di lapangan ternyata berbeda. RPD bulanan belum dapat dijadikan sebagai sumber data penyusunan perencanaan kas pemerintah. Hal ini disebabkan oleh ketidakpatuhan satker dalam menyampaikan pemutakhiran RPD bulanan ke KPPN (Steven 2017, 79). Sehingga, data penyusunan perencanaan kas saat ini hanya bersumber dari proyeksi penerimaan dan pengeluaran negara Unit Eselon I Kementerian Keuangan, RPD harian dan data historis.

\subsection{Preliminary/Exploratory Analysis}

Setelah memiliki akses ke berbagai informasi secara akurat dan timely dan sebelum menyusun proyeksi arus kas, pemerintah direkomendasikan untuk melakukan analisis pendahuluan maupun analisis exploratory. Analisis ini salah satunya berkaitan dengan data historis. Analisis terhadap data historis dapat digunakan untuk mengukur dan memetakan nature, pola, ataupun trend dari penerimaan dan pengeluaran pemerintah. Analisis pola historis ini bila dipadukan dengan jaringan informasi yang bagus dan profesional judgement yang skillful, akan menghasilkan proyeksi yang bermanfaat(Williams 2004,27).

Secara umum, analisis terhadap data historis sangat diperlukan dalam proses penyusunan perencanaan kas tingkat nasional. Historical analysis ini diperlukan untuk menyusun perencanaan kas di awal tahun pada saat sumber data actual belum terkumpul dari para supplierdata.

belanja melebihi $80 \%$ dari total pengeluaran pemerintah (Williams 2004, 28). 
Sementara itu, Direktorat PA selama ini tidak memerlukan data historis dalam penyusunan RPD Bulanan dan RPnD tingkat nasional. Dalam hal ini Direktorat PA hanya berfungsi sebagai compilator sehingga tidak melakukan preliminary analysis. Walaupun demikian, Direktorat PA, sesuai dengan fungsinya dan sesuai dengan amanat PMK 197 tahun 2017, melakukan analisis atas hasil kompilasi RPD Bulanan dan RPnD tingkat nasional yang akan dibahas pada tahapan Using Forecast.

Berdasarkan hasil wawancara dengan Pejabat Pembuat Komitmen (PPK) dan Bendahara Pengeluaran satker, data historis juga tidak terlalu berperan dalam penyusunan RPD Harian, RPD Bulanan, maupun RPnD tingkat satker. Proyeksi arus kas tingkat satker disusun dengan berdasar pada rencana pelaksanaan kegiatan ataupun rencana umum pengadaan sehingga datanya akan berbeda-beda setiap tahunnya.

Selain historical data analysis, GFOA juga merekomendasikan pemerintah untuk melakukan analisis terhadap kondisi-kondisi ekonomi yang relevan. Financial Management Capacity Building Credit/FMCBC (2013) mendefinisikan beberapa asumsi kondisi perekonomian yang dapat berpengaruh dalam penyusunan proyeksi arus kas, sebagai berikut:

a. Inflation and Consumer Price Index (CPI),

b. Uniform assessment,

c. Interest rates,

d. Taxable assessment growth,

e. Property tax revenue increase,

f. Residential and commercial expansion,

g. Fuel and oil prices,

Selain itu, pemerintah juga direkomendasikan untuk mencari pola maupun tren yang muncul secara konsisten pada hal-hal yang berhubungan dengan:

a. Business Cycles

Penyusun proyeksi sebaiknya mencari tahu apakah penerimaan dan pengeluaran pemerintah terpengaruh oleh level aktivitas ekonomi ataukah independen terhadap siklus bisnis secara nasional. Bila diketahui bahwa penerimaan dan pengeluaran mengalami fluktuasi seiring dengan naikturunnya aktivitas ekonomi, maka penyusun perencanaan kas dapat mengintegrasikan proyeksi atas berbagai indikator perekonomian untuk meningkatkan akurasi.

Hayes (2018) memberikan tiga indikator utama atas level aktivitas ekonomi secara nasional, yaitu: Produk Domestik Bruto (PDB), inflasi, dan tingkat pengangguran. PDB merepresentasikan secara langsung economic activity karena merupakan total agregat nilai uang atas semua barang dan jasa yang di produksi oleh suatu negara. Akan tetapi, terdapat sedikit kelemahan dalam penggunaan PDB sebagai indikator economic activity. Nilai uang atas produk-produk ekonomi akan tetap bertambah tiap tahunnya meskipun tidak terdapat pertumbuhan/growth. Hal ini disebabkan oleh inflasi. Karena itu, inflasi juga penting untuk diterapkan sebagai indikator tingkat economic activity. Kemudian tingkat pengangguran juga akan memberikan tambahan insight sebagai salah satu indikator. Tingkat pengangguran secara umum naik dan turun seiring perubahan atas kondisi ekonomi.

Proses penyusunan proyeksi pengeluaran pemerintah belum melakukan analisis pola dan hubungan antara pengeluaran pemerintah dengan berbagai indikator tersebut. Direktorat PKN dalam melakukan penyusunan perencanaan kas, melakukan analisis hanya terhadap data historis. Direktorat PAbahkan tidak melakukan analisis apapun dalam penyusunan RPD Bulanan dan RPnD tingkat nasional. Hal ini memang berkaitan dengan tugas Direktorat PA yang hanya sebagai compilator.

DJP di lain sisi, telah melakukan berbagai analisis atas pengaruh berbagai indikator perekonomian terhadap penerimaan pajak. Indikator yang dimaksud misalnya seperti asumsi pertumbuhan ekonomi maupun informasi pertumbuhan sektoral. Hasil analisis menunjukkan bahwa indikator tersebut tidak selalu berbanding lurus dengan pertumbuhan sektoral penerimaan pajak.

\section{b. Demographic Trends}

GFOA merekomendasikan kepada penyusun proyeksi untuk melakukan analisis pengaruh antara tren demografis terhadap permintaan kebutuhan layanan publik maupun potensi penerimaan. Neilson (2017) setuju akan rekomendasi ini dan menyampaikan bahwa dengan mengetahui hubungan antara tingkat perubahan populasi terhadap permintaan akan services dan/atau penerimaan akan membantu forecasters membuat proyeksi yang akurat. Mengetahui tren demografis akan membantu dalam penentuan volume proyeksi. Lebih lanjut lagi, analisis pengaruh ini terutama akan membantu proses penyusunan proyeksi penerimaan baik pajak ataupun bukan pajak.

Dalam wawancara, regulator RPD menyatakan bahwa tren demografis telah digunakan sebagai salah satu dasar dalam melakukan penyusunan proyeksi penerimaan dan pengeluaran negara oleh Unit Eselon I Kementerian Keuangan. Tren demografis ini berpengaruh terhadap proyeksi penerimaan perpajakan. Regulator RPD juga menyampaikan bahwa, para unit eselon I Kementerian Keuangan sebagai supplier data telah menyampaikan hal-hal yang menjadi pertimbangan maupun data pendukung dalam penyusunan proyeksi.

\section{c. Outliers and Anomalies}

Apakah data mengandung nilai yang ekstrim? Apakah dalam data terdapat nilai yang dapat men- 
dilute hasil proyeksi? Pertanyaan seperti ini sebaiknya didefinisikan dan dipetakan oleh penyusun proyeksi sejak awal. Penyusun proyeksi dituntut untuk dapat menemukan outlier yang memiliki nilai jauh berbeda dengan data lainnya. Outlierdata berisiko untuk membuat hasil proyeksi menjadi tidak proporsional dan misleading. Namun demikian, outlier juga dapat memberikan informasi hambatan dan kendala dalam proses penyusunan proyeksi. Untuk itu penting bagi para forecaster untuk mencari dan melakukan investigasi terhadap outlier dan anomali data.

Data outlier dan anomali seperti ini dapat terjadi pada saat kondisi ekonomi sedang tidak normal. Misalnya saat terjadinyabooming harga minyak atau pada kondisi ekonomi krisis. Sementara itu, data anomali dapat muncul saat kondisi beban kerja sedang tinggi. Misalnya saat akhir tahun ataupun tengah tahun ketika pencairan gaji ketigabelas maupun THR.

Direktorat PKN dalam melakukan penyusunan perencanaan kas di awal tahun melakukan investigasi untuk menangani outlier data. Investigasi ini dilakukan untuk mengolah data historis yang akan digunakan sebagai dasar penyusunan proyeksi arus kas tingkat nasional di awal tahun. Data yang diinvestigasi berasal dari berbagai supplier data, seperti: satker, kantor wilayah DJPb, KPPN, Direktorat PA, maupun unit eselon I Kementerian Keuangan.

\subsection{Selecting and Implementing Method}

Tiga langkah pertama dalam penyusunan proyeksi arus kas sesuai rekomendasi GFOA dilakukan untuk membantu proses pemilihan dan implementasi metode forecasting. Berbagai informasi yang didapatkan dari analisis dan investigasi atas asumsi, data historis, maupun kondisi ekonomi akan memberikan insight/wawasan bagi penyusun proyeksi untuk dapat menentukan mana metode penyusunan perencanaan kas yang tepat. Berikut ini pembahasan mengenai pemilihan metode dan implementasi metode perencanaan kas pemerintah:

\section{a. Selecting methods}

Setelah berbagai pola/pattern telah diidentifikasi, maka selanjutnya penyusun proyeksi dapat memilih metode forecasting yang paling sesuai. GFOA merekomendasikan kepada forecasters untuk memilih metode berdasarkan kebutuhan dan kondisi yang sedang terjadi. Metode yang sederhana membutuhkan data yang sedikit, pengalaman dan keahlian forecasters yang minimal, dan juga memerlukan effort yang ringan. Sedangkan metode yang lebih kompleks membutuhkan usaha dan pemahaman lebih besar. Walaupun metode yang kompleks cenderung menghasilkan tingkat akurasi yang lebih tinggi, metode sederhana dinilai oleh GFOA juga mampu untuk menunjukkan ratarata performa yang sama baiknya.
Sesuai dengan informasi yang disampaikan oleh regulator RPD Bulanan, metode penyusunan proyeksi kas sengaja dibuat se-sederhana mungkin. Hal ini dilakukan dalam rangka memberikan kemudahan bagi satker untuk melakukan perencanaan kegiatan. Karena setelah bertahuntahun diterbitkan peraturan tentang perencanaan kas, tingkat kepatuhan satker dalam penyusunan RPD Bulanan masih rendah. Oleh karena itu, diperlukan penyederhanaan mekanisme perencanaan kas.

Sementara itu, regulator RPD Harian dan Proyeksi Penerimaan/Pengeluaran Negara mengatakan bahwa metode forecasting yang menggunakan model statistik memerlukan effort yang sangat besar. Sebelum digunakan, suatu model perlu untuk dikaji secara menyeluruh. Kemudian perlu untuk dilakukan pengkajian, uji coba, maupun piloting. Selain itu, diperlukan pula data awal yang lengkap yang masih belum tersedia pada saat awal penyusunan perencanaan kas di Indonesia. Oleh karena itu, dipilihlah metode yang menggunakan indeks data historis. Jadi metode yang dipilih adalah metode yang lebih sederhana akan tetapi tetap memasukkan unsur perhitungan statistik.

Menurut Tangsucheeva dan Prabhu (2014, 65), terdapat dua kategori alternatif metode forecasting, yaitu receipts and disbursement forecast technique dan statistical technique. Metode forecasting yang pertama adalah dengan penggunaan metode yang lebih sederhana, yaitu memanfaatkan data arus kas pada beberapa periode sebelumnya untuk membuat jadwal penerimaan dan pengeluaran untuk periode selanjutnya. Metode seperti ini sangat bergantung pada appropriate forecast adjustments atas setiap item arus kas guna menjaga tingkat akurasi. Metode yang kedua menggunakan teknik yang lebih canggih dan kompleks dengan mengintegrasikan historical trends. Teknik statistik seperti ini misalnya: simple moving average, exponential smoothing, regression analysis, dan distribution model (WWCP 2012, 12). Konsep dasar dari berbagai metode ini memanfaatkan sifat data dan perilaku historis yang cenderung terulang atau menggambarkan apa yang akan terjadi di masa yang akan datang.

\section{b. Implementing Methods}

Langkah selanjutnya menurut rekomendasi GFOA terdiri dari penyusunan proyeksi dan penentuan range/kisaran hasil proyeksi. Pemerintah, setelah menentukan metode forecasting yang paling sesuai, dapat melakukan penyusunan proyeksi arus kas dengan mengimplementasikan satu atau lebih teknik yang telah di bahas pada sub-bab sebelumnya. Yang perlu menjadi catatan, pemerintah direkomendasikan untuk men-develop suatu kisaran hasil proyeksi berdasarkan berbagai skenario yang mungkin terjadi. Misalnya skenario saat keadaan resesi, 
normal, ataupun booming/ekspansif.

Direktorat PKN dalam melakukan penyusunan perencanaan kas menghasilkan multiple projection pada saat kondisi status saldo kas dalam keadaan tidak normal. Direktorat PKN mengategorikan kondisi status kas menjadi lima macam, yaitu: status krisis, siaga, waspada, normal, dan berlebih (rincian status kas dapat dilihat pada Tabel 6).

Tabel 6. Status Kondisi Saldo Kas

\begin{tabular}{ll}
\hline Status Kas & Saldo Kas \\
\hline Status Krisis & $0-50$ trilyun \\
\hline Status Siaga & 51 trilyun -76 trilyun \\
\hline Status Waspada & 77 trilyun -90 trilyun \\
\hline Status Normal & $91-120$ trilyun \\
\hline Status Berlebih & $>121$ trilyun \\
\hline Sumber: Direktorat Pengelolaan Kas Negara, DJPb
\end{tabular}

Dalam keadaan kas normal ataupun berlebih, maka tidak perlu disediakan opsi/alternatif proyeksi. Kemudian bila keadaan kas berstatus waspada, siaga ataupun krisis ekonomi, Direktorat PKN perlu menyediakan alternatif nilai perencanaan kas dengan memperhatikan opsi-opsi kebijakan yang dapat diambil oleh pimpinan. Misalnya, untuk mengatasi shortfall penerimaan dan kekurangan kas, pemerintah dapat melakukan pinjaman atau melakukan penghematan anggaran $\mathrm{K} / \mathrm{L}$ (self blocking).

\subsection{Using Forecast}

Proyeksi arus kas secara umum dapat dimanfaatkan sebagai alat untuk meningkatkan akurasi perencanaan utang maupun investasi. Hasil proyeksi dapat membantu dalam proses pengambilan keputusan dengan cara mengidentifikasi potensi terjadinya kas surplus ataupun timbulnya gap dalam arus kas. Dengan demikian, fungsi utama dari penyusunan proyeksi adalah membantu menyediakan informasi untuk proses pengambilan keputusan. GFOA memformulasikan tiga hal yang penting dalam rangka penyampaian proyeksi arus kas yang informatif dan compelling, sebagai berikut:

\section{a. Credibility of the Forecaster}

Kemampuan dan kualitas SDM penyusun proyeksi merupakan salah satu hal yang esensial untuk meningkatkan predictive value. Muthohar (2012, 109) menemukan bahwa kualitas SDM merupakan salah satu faktor yang mempengaruhi secara signifikan tingkat efektifitas perencanaan kas. Hasibuan $(2016,84)$ kemudian menambahkan faktor kuantitas SDM selain kualitas SDM yang berpengaruh dalam penyusunan proyeksi arus kas pemerintah pusat.

Menurut Subagio dalam wawancara, kualitas SDM di Kementerian Keuangan, DJPb, dan KPPN sudah cukup bagus. Begitu pula dengan kualitas
SDM di K/L. Hanya saja menurutnya, SDM di K/L kurang dapat memahami apa yang diinginkan oleh regulator. Jadi satker belum melaksanakan penyusunan proyeksi arus kas dengan sungguhsungguh karena beranggapanbahwa perencanaan kas hanya untuk kepentingan sektoral Kementerian Keuangan/BUN.

Regulator RPD Bulanan juga menyampaikan bahwa kualitas SDM dari sisi pengelolaan keuangan satker sebenarnya telah cukup. Apalagi dengan peran serta KPPN yang terus membina satker di lingkup kerjanya. Namun, perlu diperhatikan kemauan dan pemahaman akan fungsi perencanaan kas. Regulator RPD Harianmaupun SPV KPPN Jakarta II menyampaikan hal yang sama. Kualitas SDM pada satker dinilai cukup untuk melakukan penyusunan proyeksi arus kas. Apalagi mekanisme penyusunan RPD sudah dibuat sangat sederhana sehingga mudah dipelajari.

Tingkat kualitas SDM dapat tercermin pada produk akhir proyeksi arus kas. Seperti telah disampaikan sebelumnya, proyeksi arus kas tingkat satker akan bermuara pada perencanaan kas tingkat nasional yang disusun oleh Direktorat PKN. Dengan kata lain, data RPD, RPnD, Proyeksi Penerimaan dan Pengeluaran Negara akan diolah menjadi perencanaan arus kas dan proyeksi saldo kas pemerintah. Hal ini sejalan dengan apa yang disampaikan Direktorat PKN bahwa untuk mengukur efektivitas dari perencanaan kas digunakan indikator tingkat akurasi atau deviasi antara target dengan realisasinya. Jika unit-unit supplier data menyampaikan data yang rendah tingkatvaliditasnya tentu dalam penyusunan perencanaan kas akan mengikuti data tersebut.

Pada Gambar 6, tingkat akurasi pengeluaran kas pemerintah pusat tahun 2015 dan 2016 tidak begitu bagus bila dilihat dari tingkat selisih antara proyeksi dengan realisasinya. Pada tahun 2015, persentase selisih mencapai angka di atas $27 \%$ di bulan Agustus. Sedangkan selisih terbesar di tahun 2016 terjadi di bulan Maret dengan nilai sebesar $31 \%$. Secara rata-rata, tingkat selisih antara proyeksi dengan realisasi pengeluaran kas pemerintah pusat bergerak fluktuatif di kisaran angka $15 \%$. Salah satu hal yang perlu diapresiasi adalah Direktorat PKN mampu menjaga proyeksi cash outflow pemerintah tidak kurang dari realisasinya. Penulis menemukan hanya pada bulan Januari 2016 nilai proyeksi belanja Pemerintah Pusat lebih kecil dari realisasinya.

Permasalahannya, persentase selisih proyeksi dan realisasi penerimaan negara memiliki nilai yang lebih besar bila dibandingkan dengan selisih proyeksi pengeluaran. Sebagaimanapada Gambar 7, tingkat selisih proyeksi dengan penerimaan negara pada bulan September tahun 2015 mencapai 50 persen. Sementara itu, persentase selisih pada tahun 2016 paling tinggi terjadi di bulan Februari dengan nilai hampir 40 persen. Bila diperhatikan 
52

Gambar 6. Selisih Proyeksi dengan Realisasi Pengeluaran Bulanan Pemerintah Pusat Tahun 2015-2016

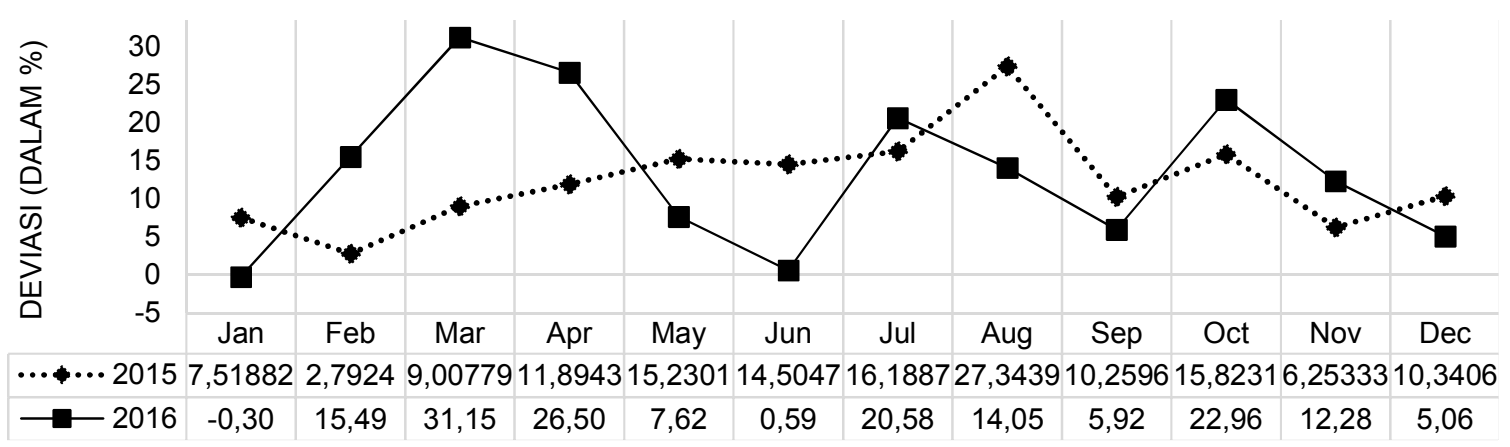

Sumber: Diolah dari data proyeksi perencanaan kas Direktorat PKN

lebih lanjut, terdapat nilai negatif persentase selisih pada tahun 2015. Dengan kata lain, realisasi penerimaan lebih kecil daripada proyeksinya dan menandakan telah terjadi shortfall. Sebaliknya, pada tahun 2016 selisih negatif tidak terjadi lagi dan realisasi penerimaan tidak pernah lebih kecil daripada proyeksi.

Untuk dapat meningkatkan predictive value, GFOA merekomendasikan kepada pemerintah supaya berusaha untuk menjaga tingkat akurasi proyeksi selalu dalam batas toleransi. Untuk mendorong satker agar berusaha menjaga tingkat akurasi proyeksi, Direktorat PKN dapat memberikanreward bagi satker yang mampu menjaga tingkat deviasi RPD Harian di bahwa lima persen sebagaimana diatur dalam PMK 197 tahun 2017.

Selain itu, GFOA juga merekomendasikan transparansi proses penyusunan proyeksi arus kas. Mekanisme forecasting yang transparan akan membuat hasil proyeksi semakin compelling dan informatif. Berdasarkan hasil wawancara, para informan sepakat bahwa mekanisme dan pelaksanaan penyusunan proyeksi arus kas di tingkat satker, KPPN, maupun Kantor Pusat telah berjalan dengan transparan.

\section{b. Presentation Approach}

Mengingat fungsi proyeksi arus kas merupakan alat bantu proses pengambilan keputusan, maka bagaimana hasil proyeksi disampaikan/dipresentasikan menjadi hal yang krusial. Oleh karena itu, forecasters direkomendasikan untuk bekerja sebaik-baiknya dalam mengolah data supaya dapat menampilkan hasil proyeksi yang memiliki pesan yang jelas. Pelaporan proyeksi arus kas yang jelas, sederhana, dan reasonable, menurut GFOA, merupakan hal yang vital untuk mewujudkan presentation approach yang compelling.

Dalam wawancara, para informan dari satker yang terdiri dari PPK, staf PPK, bendahara pengeluaran sependapat bahwa format penyampaian RPD sudah sederhana dan informatif. Informasi yang ditampilkan dalam Laporan RPD Harian meliputi jenis belanja, jumlah dana, dan jenis transaksi (contoh Laporan RPD Harian dapat dilihat pada Lampiran Gambar 8). Sementara itu, format penyampaian RPD Bulanan mengandung lebih banyak informasi, seperti kode kegiatan, output, komponen, subkomponen, jenis belanja, jumlah pagu, jadwal pelaksanaan kegiatan dan jumlah penarikan dana seperti ditampilkan pada Lampiran Gambar 9. Banyaknya informasi yang harus disiapkan oleh satker menimbulkan kerumitan dan menyebabkan satker menjadi tidak patuh dalam penyusunan RPD Bulanan (Steven 2017, 41).

Namun demikian, format penyampaian RPD tingkat satker belum dapat menampilkan keterangan asumsi/pertimbangan yang digunakan dalam proses penyusunan RPD. GFOA merekomendasikan forecasters untuk menampilkan asumsi dengan jelas. Forecasters sebaiknya menjelaskan bagaimana asumsi ataupun pertimbangan profesional yang digunakan mempengaruhi hasil proyeksi. Forecasters juga dianjurkan untuk membekali laporan dengan informasi tambahan yang diperlukan oleh pimpinan.

\section{c. Linking Forecast to Decision-Making}

Fungsi penyusunan perencanaan kas adalah sebagai alat untuk membantu dalam proses pengambilan keputusan, utamanya di bidang manajemen kas. Pada langkah terakhir penyusunan perencanaan kas ini, pemerintah diharapkan dapat menggunakan informasi yang disediakan oleh proyeksi untuk menentukan berbagai kebijakan.

Sebagai contoh, perencanaan kas dimanfaatkan dalam rangka menjaga structural balance keuangan pemerintah. Kebijakan ini dilakukan untuk memastikan bahwa setiap pengeluaran pemerintah dalam satu waktu dapat sepenuhnya di-cover oleh penerimaan. Proyeksi arus kas diperlukan untuk memprediksi terjadinya kekurangan kas sehingga pemerintah dapat segera 
menyiapkan alternatif pembiayaan sehingga perencanaan kas dapat digunakan sebagai early warning system terjadinya shortfall menutupi kekurangan kas atau mengoptimalkan kelebihan kas.

Gambar 7. Selisih Proyeksi dengan Realisasi Penerimaan Bulanan Pemerintah Pusat Tahun 2015-

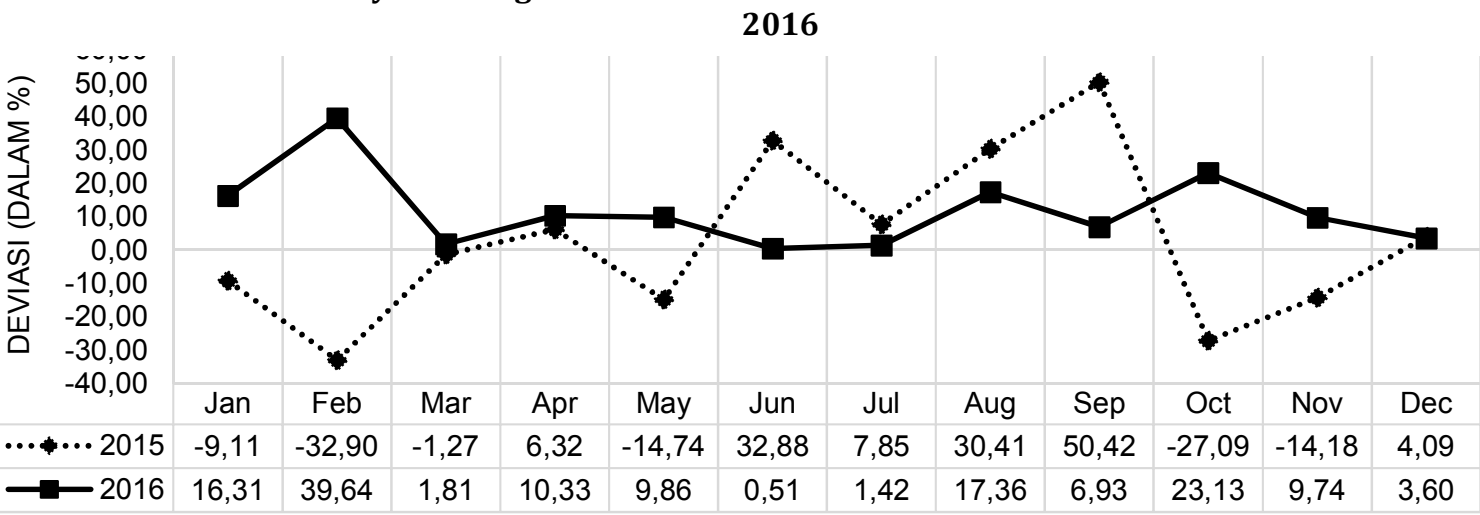

Sumber: Diolah dari data proyeksi perencanaan kas Direktorat PKN

Structural balance keuangan pemerintah menjadi sulit untuk dijaga di tengah rendahnya tingkat realisasi penerimaan negara. Sebagaimana padaGambar 10, sejak tahun 2009 realisasi penerimaan perpajakan tidak pernah mencapai target. Bahkan, gap antara target dengan realisasi terus melebar hingga akhir tahun 2016.

Shortfall penerimaan perpajakan dapat terjadi karena dua kemungkinan. Pertama, mungkin karena memang kinerja pemerintah kurang efektif merealisasikan penerimaan ataupun bisa terjadi karena pemerintah menetapkan target/proyeksi penerimaan yang terlampau tinggi. Gunawan dan Hermansyah (2016) lebih setuju pada kemungkinan kedua dan percaya bahwa target penerimaan perpajakan ditetapkan terlalu optimis. Mereka berargumen bahwa meskipun penerimaan pajak terus naik, tetapi shortfall yang terjadi di tahun 2015 dan 2016 merupakan yang terbesar satu dasawarsa terakhir.

Proyeksi penerimaan yang terlalu optimis dapat berdampak negatif pada structural balance keuangan pemerintah. Pemerintah dalam menganggarkan pengeluaran tentu akan berpatokan pada rencana penerimaan. Bila proyeksi penerimaan tidak tercapai, maka akan menimbulkan mismatch menyebabkan posisi kas masuk ke dalam status tidak normal.

Direktorat PKN menyampaikan bahwa cukup sering terjadi mismatch/ketidaksesuaian antara penerimaan dengan pengeluaran negara. Oleh karena itu, perencanaan kas yang valid dan akurat diperlukan untuk mengetahui kondisi penerimaan, belanja dan selisih lebih atau selisih kurang pembiayaan agar dapat diambil kebijakan yang tepat sesuai dengan kondisi kas yang ada, seperti
Selain itu, perencanaan kas juga penting dalam pelaksanaan kebijakan cash buffer/saldo kas minimal yang optimal(Mu 2006, 10). Pengendalian dan prakiraan kas yang lebih akurat akan memungkinkan DJPb untuk memberikan saran mengenai cara-cara menstabilkan profil kas (dan karenanya mengurangi cash buffer) melalui strategi penerbitan dan pembayaran utang. Upaya menurunkan rata-rata cash buffer pada rekening milik pemerintah Indonesia akan menekan biaya penerbitan utang yang tidak perlu dan akan memungkinkan adanya penempatan cash pada investasi berjangka (World Bank 2014, 172).

Meskipun pemerintah dapat meminimalkan cash buffer, tetapinilainya tidak akan sampai pada angka nol. Hal ini karena cash buffer tidak hanya dipergunakan untuk menutup pengeluaran rutin tetapi juga untuk menanggulangi pengeluaran yang tidak dapat diperkirakan sebelumnya.

\section{KESIMPULAN DAN SARAN}

Hasil evaluasi yang telah dilakukan penulis menunjukkan bahwa mekanisme penyusunan perencanaan kas pemerintah pusat belum sesuai sepenuhnya dengan framework GFOA.Terdapat berbagai perbedaan dengan cash forecasting framework diantaranya terkait dengan lingkup tujuan perencanaan kas, time-frame, exploratory analysis, maupun penggunaan cash forecasting oleh pengelola keuangan.

Pemerintah pusat belum mengintegrasikan fungsi perencanaan kas di bidang kebijakan moneter. Dengan demikian, untuk dapat memaksimalkan peranan perencanaan kas, DJPb c.q. Direktorat PKN dan Direktorat PA selaku pihak yang bertanggung jawab atas perencanaan kas 
pemerintah pusat perlu meningkatkan koordinasi dengan Bank Indonesia untuk mengintegrasikan hasil proyeksi sebagai tool pelaksanaan kebijakan moneter. Perencanaan kas penting untuk memprediksi posisi saldo kas dan penempatan excesscash di pasar uang.

Sementara itu, time horizon/forecast horizon mesti telah terukur, tetapi belum cukup panjang untuk memberikan jeda waktu yang cukup saat terjadi shortfall. Pelaksanaan RPD Bulanan belum berjalan dengan maksimal sehingga belum dapat digunakan sebagai dasar acuan penyusunan perencanaan kas Pemerintah Pusat. Di lain sisi, meskipun hasil perencanaan kas sudah dapat bermanfaat untuk menjaga likuiditas Pemerintah Pusat, namun perencanaan kas belum berhasil memperbaiki informasi pengelolaan kas dalam DIPA.

Selain itu, pemerintah belum pernah melakukan analisis pendahuluan/preliminary analysis pada awal penyusunan perencanaan kas. Oleh karena itu,pemerintah perlu melakukanpenelitian lebih lanjutan untuk mencari tahu pengaruh berbagai indikator aktivitas ekonomi seperti GDP, inflasi, dan tingkat pengangguran terhadap belanja pemerintah. Selain itu, selanjutnya perlu dilakukan penelitian tentang analisis pengaruh antara tren demografis terhadap permintaan akan layanan publik dan potensi penerimaan.

Pemanfaatan pendekatan top-down dalam pengembangan model prakiraan kas pemerintah dapat menjadi alternatif guna memperoleh tingkat akurasi proyeksi kebutuhan kas yang diharapkan. Selain itu, pendekatan top-downdapat menjadi alternatif baru untuk mengumpulkan informasi yang diperlukan dalam penyusunan perencanaan kas. Hal ini dikarenakan, pendekatan top-down dapat mengeliminasi permasalahan rendahnya peran serta dan ketertiban data supplier dalam menyediakan informasi. Misalnya data RPD Bulanan yang belum disampaikan oleh satker.Untuk menerapkan hal ini, diperlukan penyesuaian peraturan perundangan yang saat ini masih berlaku.

Hal lain yang perlu menjadi catatan adalah terkait kualitas penyusun proyeksi di tingkat satker. SDM penyusun proyeksi di tingkat satker sudah dapat dikatakan cukup baik kompetensinya. Hanya saja, kemauan SDM untuk menyusun RPD Bulanan dinilai masih kurang. Satker masih banyak yang beranggapan bahwa perencanaan kas hanyalah berguna untuk kepentingan sektoral BUN.Selain itu, penyusun proyeksi juga masih belum terlalu paham akan tujuan dan peran penting perencanaan kas.

Untuk memperbaiki persepsi dan meningkatkan kepedulian satker, pemerintah perlu merevisi materi yang disampaikan dalam sosialisasi tentang perencanaan kas. Jadi satker tidak hanya diberikan materi teknis tentang mekanisme penyusunan proyeksi tetapi juga hal-hal fundamental seperti konsep dasar maupun sasaran prioritas perencanaan kas. Tujuannya adalah supaya semua stakeholders paham betul tujuan, asumsi, dan sudut pandang pemerintah terkait perencanaan kas.

\section{REFERENSI}

Alfiah, Ikmal Fitriyani. (2016). Evaluasi penerapan perencanaan kas dan faktor-faktor yang mempengaruhi efektivitas perencanaan kas di tingkat satuan kerja pada wilayah pembayaran KPPN Padang. Tesis. Padang: Universitas Andalas.

Bagaskoro, Gading. (2016). Analisis faktor-faktor yang mempengaruhi efektivitas perencanaan kas satuan kerja lingkup pembayaran KPPN Jakarta III. Skripsi. Tangerang Selatan: PKN STAN.

Centre for Indonesia Taxation Analysis (CITA),diakses 18 Maret 2018 dari https://cita.or.id/tag/penerimaan-pajak/

Financial Management Best Practice Committee (FMCBC). (2013). Financial forecasting: budget preparation \& cash flow forecasting. Best Practice: FMCBC.

Government Finance Officers Association (GFOA). (2013). Financial forecasting: Budget preparation \& cash flow forecasting. Core Best Practice: GFOA.

Gunawan, Arif S., \& Hermansyah, Anton. (2016). Behind tax-shortfall: rethinking Indonesian taxation. The Jakarta Post, diakses dari http://www. thejakartapost .com/ news/2016/01/12/ behind-tax- shortfallrethinking- indonesian-taxation.html

Haryanto, J. Dodik, \& Wihascaryo, Adithya Bayu. (2011). Evaluasi penerapan perencanaan kas di tingkat satuan kerja. Jakarta: Sub Bagian Pengembangan Sekretariat Direktorat Jenderal Perbendaharaan.

Hasibuan, Grace R. M. (2016). Analisis efektivitas perencanaan kas dalam pelaksanaan anggaran satuan kerja pada lingkup pembayaran KPPN Jakarta II. Skripsi. Tangerang Selatan: PKN STAN.

Hayes, Adam. Investopedia. Economic basics: measuring economic activity. Diakses 20 Juni 2018 dari https: //www.investopedia.com /university/economics/economicmeasuring-economy-activity.asp

Huda, Samsul. (2010). Kajian yuridis atas rencana penarikan dana dalam DIPA dan implikasinya terhadap keberhasilan pelaksanaan anggaran. Tesis. Jogjakarta: Universitas Gadjah Mada. 
Indra, Rolly, \& Helmy Adam. (2014). Evaluasi implementasi manajemen kas pemerintah pusat (studi kasus pada Direktorat Pengelolaan Kas Negara Ditjen Perbendaharaan). Malang: Fakultas Ekonomi dan Bisnis Universitas Brawijaya.

Lienert, Ian. (2009). Modernizing cash management. IMF Fiscal Affairs Department.

$\mathrm{Mu}$, Yibin. (2006). Government cash management: good practice and capacity building framework. World Bank.

Murwanto, Rahmadi, Insyafiah, \& Subkhan. (2006). Manajemen kas. Jakarta: Lembaga Pengkajian Keuangan Publik dan Akuntansi Pemerintah.

Muthohar, Aziz. (2012). Faktor-faktor utama yang mempengaruhi efektivitas perencanaan kas satuan kerja kementerian negara/lembaga lingkup wilayah pembayaran KPPN Jakarta II. Tesis. Jakarta: Universitas Indonesia.

Neilson, Jeff. (2017). Forbes community voice. Forecasting and Budgeting Can Improve Your Company's Fiscal Performance. Diakses 20 Juli 2018 dari https://www.forbes.com/sites/ forbesagencycouncil/2017/02/03/forecasti ng-and-budgeting-can-improve-yourcompanys-fiscalperformance/ \#7d7233f24fc2

Peraturan Menteri Keuangan Nomor 197/PMK.05/2017 tentang Rencana Penarikan Dana (RPD), Rencana Penerimaan Dana (RPnD), dan Perencanaan Kas. Jakarta: Kementerian Keuangan.

Peraturan Pemerintah Nomor 39 Tahun 2007 tentang Pengelolaan Uang Negara/Daerah. Jakarta: Republik Indonesia

Seftianova, Ratih, \& Helmy Adam. (2013). Pengaruh kualitas DIPA dan akurasi perencanaan kas terhadap kualitas penyerapan anggaran pada satker wilayah KPPN Malang. JRAK Vol. 4, No. 1, Hal. 75-84. Malang: Universitas Brawijaya.

Septiawan, Bagus. (2016). Penggunaan teknik data mining dalam klasifikasi akurasi rencana penarikan dana tingkat satuan kerja (studi kasus pada satuan kerja lingkup KPPN Jakarta I dan IV). Skripsi. Tangerang Selatan: PKN STAN.

Steven. (2017). Analisis efektivitas penerapan perencanaan kas pemerintah pusat. Skripsi. Tangerang Selatan: PKN STAN.

Suselo, Sri L., Shinta R. I. Soekro, \& R. Aga Nugraha. (2013). Sekuritas aset lembaga pembiayaan dan pengembangan pasar secondary mortgage facility dalam rangka pendalaman pasar keuangan indonesia. Jakarta: BI Working Paper.

Suwardi, Themin. (2012). Ask the SMU professor: cash is king. The SME Magazine, 20 Maret, 40,
Diakses $24 \quad$ Juli 2018 dari http://ink.library.smu.edu.sg/soa_research

Swaramarinda, Darma Rika, \& Susi Indriani. (2011). Pengaruh pengeluaran konsumsi dan investasi pemerintah terhadap pertumbuhan ekonomi Indonesia. Econo Sains IX: 95-105.

Tamba, Eli, \& Wibawa. (2008). Modul manajemen kas. Direktorat Jenderal Perbendaharaan.

Tangsucheeva, Rattachut, \& Vittaldas Prabhu. (2014). Stochastic financial analytics for cash flow forecasting. International J. Production Economics (pp. 65-76).

Williams, Mike. (2004). Government Cash Management: Good and Bad Practice. International Technical Note: IMF.

World Wide Country Profiles (WWCP), (2012). AFP guide to strategic global cash position forecasting. Glob. Liq. Guide Ser. 1, 1-22 (Association for Financial Professionals). 


\section{Lampiran}

Gambar 8. Laporan RPD Harian Satker KPPN Jakarta II

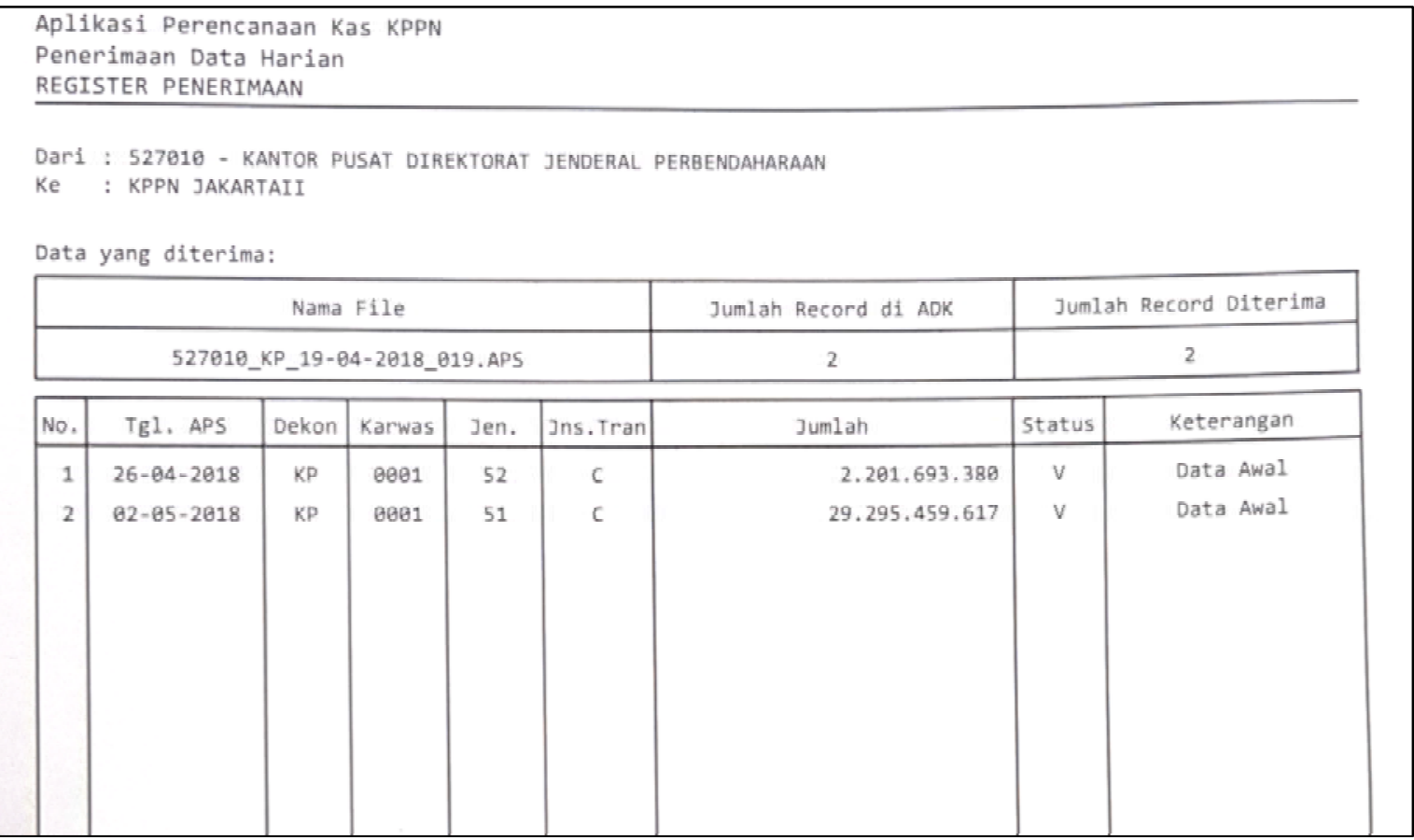

Sumber: Aplikasi Perencanaan Kas KPPN Jakarta II

Gambar 9. Format RPD Bulanan

RENCANA PENARIKAN DANA BULANAN TINGKAT SATKER TA 2OXX

\begin{tabular}{|c|c|c|c|c|c|c|c|c|}
\hline \multicolumn{3}{|c|}{$\begin{array}{l}\text { Kementerian } \\
\text { Negara/Lembaga }\end{array}$} & \multicolumn{6}{|l|}{$:$} \\
\hline \multicolumn{3}{|c|}{ Unit Eselon I/Program } & \multicolumn{6}{|l|}{ : } \\
\hline \multicolumn{3}{|c|}{ Satker } & \multicolumn{6}{|l|}{ : } \\
\hline Kode & Uraian & Pagu & Jan & Feb & Mar & $\ldots$. & Des & Jumlah \\
\hline (1) & (2) & (3) & (4) & (5) & (6) & & (15) & (16) \\
\hline
\end{tabular}

Catatan: Form ini digunakan untuk tingkat Satker, Unit Eselon I dan K/L

Tata Cara Pengisian Rencana Penarikan Dana Bulanan:

(1) Diisi kode Kegiatan, Output,Komponen, Subkomponen, dan jenis belanja

(2) Diisi uraian Kegiatan, Output,Komponen, Subkomponen, dan jenis belanja

(3) Diisi jumlah pagu

(4) s.d. (15) Diisi sesuai jadwal pelaksanaan kegiatan

(16) Diisi jumlah penarikan dana untuk setiap bentuk kegiatan per jenis belanja.

Sumber: Penjelasan PMK 197 tahun 2017 
Gambar 10. Realisasi Penerimaan Perpajakan 2006-2016

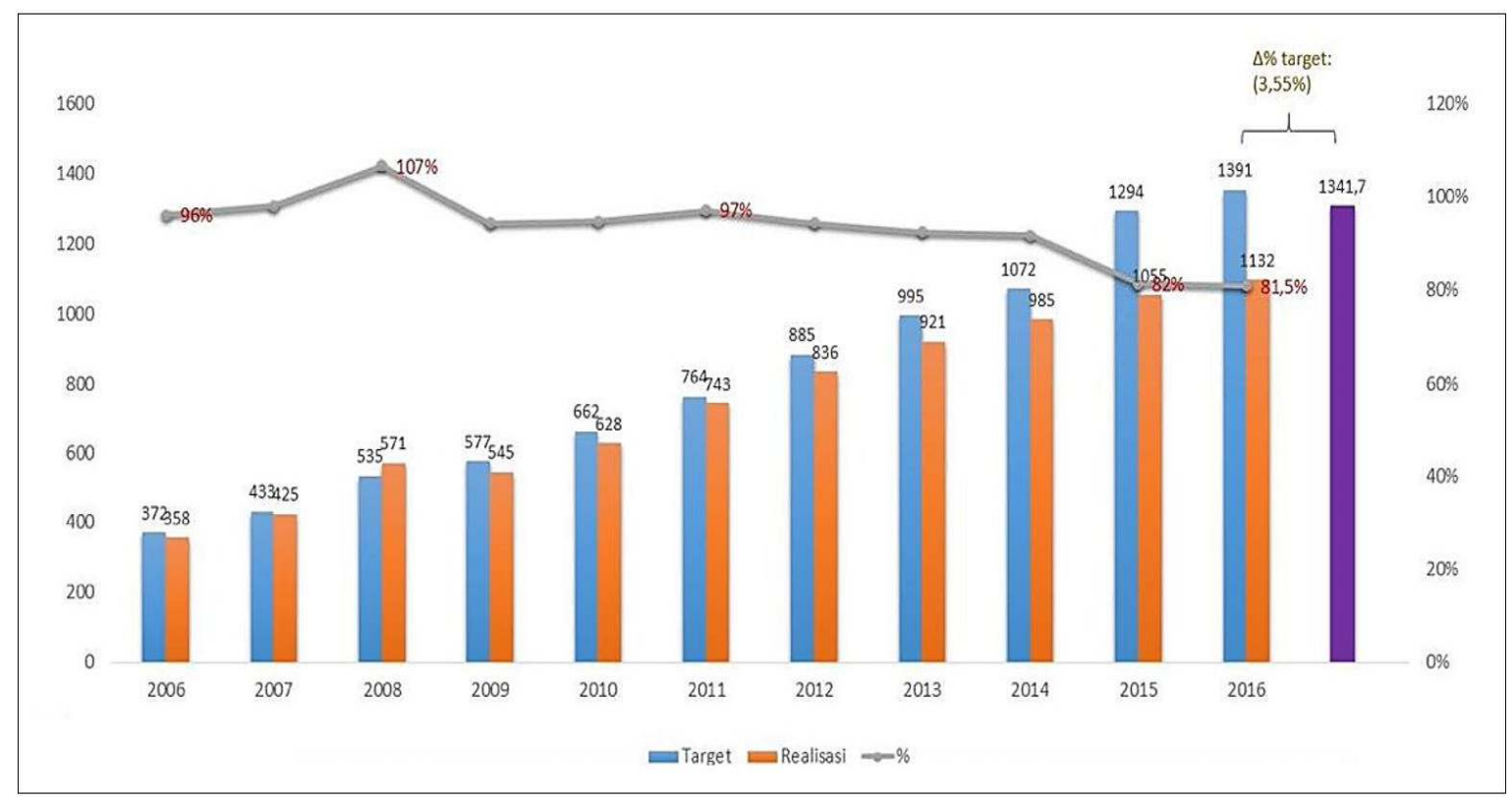

Sumber: Center for Indonesia Taxation Analysis (CITA), 2017 